\title{
10 \\ How Do Subduction Zones Regulate the Carbon Cycle?
}

\author{
MATTHIEU EMMANUEL GALVEZ AND MANUEL PUBELLIER
}

\subsection{Carbon Distribution on Earth}

The core, mantle, and crust contain more than $99 \%$ of Earth's carbon stocks. ${ }^{1}$ The remaining $1 \%$ is in the fluid Earth, split between the biosphere, atmosphere, and oceans. But this distribution must be considered as a snapshot in time, not a fixed property of the Earth system. Continuous exchange of carbon between fluid (ocean, atmosphere, and biosphere) and solid Earth (mainly mantle and crust) has modified the size of the fluid and solid carbon reservoirs ${ }^{2}$ over geological time, regulating atmospheric composition and climate. $^{3,4}$ The subduction zone, where converging tectonic plates sink below one another or collide, is the main pathway for this exchange. It will be the focus of this chapter.

Geologists believe that a long-term shift in regime of subduction carbon cycling is underway. Following an ecological innovation - the evolution of open-ocean calcifiers (e.g. coccolithophores and foraminifera) in the Mesozoic, marine regression and other changes $^{5}$ - it is thought that the accumulation of carbonates on the seafloor (pelagic) has increased over the Cenozoic to reach about $50-60 \%$ of the global rate today (Table 10.1). ${ }^{5-7}$ Most of the carbonate that has accumulated over the last 100 Myr has not subducted yet (Table 10.1) and should do so sometime in the coming hundreds of millions of years. But when this will happen is unknown because there is no direct link between the precipitation of carbon on the seafloor and the birth of a subduction zone. Irrespective of when it happens, because the fates of shelf and deep-sea carbon materials differ, it has been proposed that intensification of deep-ocean carbonate deposition may eventually affect the prevailing regime of geological carbon cycling.., 9

To understand the link between oceanic carbon deposition centers and modes of longterm carbon cycling, we need to consider the fate of sedimentary carbon. Shelf and oceanic island carbon mostly escapes subduction and is accreted to continents during continental subduction and collision. While a fraction of pelagic carbon can also be thrusted within accretionary wedges and accreted, most $^{10}$ is bound to be subducted, dissolved, or molten at various depths (Figure 10.1) within the sinking plate, before being released in the forearc, ${ }^{11}$ arc, ${ }^{12}$ or back-arc regions, ${ }^{13}$ or mechanically incorporated deeper into the mantle. The contrasted fate distinguishes two principal modes of tectonic carbon cycling: the shallow accretionary carbon cycle and the relatively deeper subduction zone carbon cycle (Figure 10.1). What is not clear yet is how fast those cycles operate and how they interact. 
Table 10.1 Estimates of total annual carbon flux, reservoir sizes, and residence times for various components of the carbon cycle.

\begin{tabular}{|c|c|c|c|c|}
\hline & $\begin{array}{l}\text { C flux } \\
\mathrm{Mt} / \mathrm{yr}\end{array}$ & $\begin{array}{l}\text { Reservoir }^{a} \\
\left(\times 10^{9} \mathrm{MtC}\right)\end{array}$ & $\begin{array}{l}\text { Residence time, }{ }^{b} \\
\tau(\mathrm{Myr})\end{array}$ & Refs. \\
\hline \multicolumn{5}{|c|}{ Sedimentary carbonate } \\
\hline Total deposition & 210-240 & - & - & {$[5]$} \\
\hline Continental $^{c}$ & $60-120$ & $64 \pm 14$ & $\sim 500-1100$ & {$[6]$} \\
\hline Pelagic & $120-150$ & $9.3 \pm 4.3$ & $\sim 60-75$ & {$[5,6]$} \\
\hline Subduction $^{d}$ & $40-60$ & - & - & [26] \\
\hline \multicolumn{5}{|c|}{ Organic matter $(\mathrm{OM})$} \\
\hline Total deposition ${ }^{e}$ & $160-200$ & - & - & {$[43,145]$} \\
\hline Accretion & $130-185$ & $11 \pm 3$ & $\sim 70$ & {$[43,145,146]$} \\
\hline Pelagic & $15-30$ & $1.6 \pm 0.8$ & $\sim 53-160$ & [29] \\
\hline Subduction & $\sim 10$ & - & - & [26] \\
\hline $\begin{array}{l}\text { Hydrothermal } \\
\text { carbonate total }\end{array}$ & $>26-45 ?$ & - & - & \\
\hline $\begin{array}{l}\text { Subduction }(\mathrm{AOC}+ \\
\mathrm{UM})^{f}\end{array}$ & $26-45$ & $9.3 \pm 4.3$ & - & {$[18]$} \\
\hline Arc outgassing & $\sim 18-43$ & - & - & {$[21]$} \\
\hline
\end{tabular}

${ }^{a}$ Reservoir size from Ref. 83.

${ }^{b}$ Residence time is estimated by assuming a homogeneous reservoir and by dividing reservoir size by flux. Because geological reservoirs are heterogeneous, the mean age of $\mathrm{C}$ in those reservoirs should greatly exceed their theoretical residence times.

${ }^{c}$ Obtained from the difference between total deposition flux and total pelagic deposition flux provided by Ref. 5 .

${ }^{d}$ Note that the Cenozoic average estimated by Ref. 26, in part based on Ref. 25, exceeds the estimate from Ref. 21. The pelagic deposition flux exceeds the carbonate subduction flux, which suggests net accumulation of carbonate in the pelagic reservoir.

${ }^{e}$ This total contains a fraction of partially graphitic petrogenic materials, estimated by Ref. 33 to be around $40 \mathrm{Mt} / \mathrm{yr}$. The large spread of estimates of organic carbon (OC) burial (as in Ref. 29) is in part due to the variety of depositional environments considered and to the different definitions of what "burial" of biospheric OM means for different authors. For example, the estimates of Ref. 43 (on which the re-evaluations of Ref. 145 are based) accounts for a global 20 wt.\% diagenetic loss by decarboxylation before OC is effectively "buried." Loss of hydrocarbons during catagenesis in accretionary wedges may reduce by another $20 \%$ or more ( $>25 \mathrm{Mt} / \mathrm{yr}$ ) the amount of OC that eventually subducts.

${ }^{f} \mathrm{AOC}=$ altered oceanic crust (22-28 Mt/yr); UM = hydrothermally altered upper mantle (4-15 Mt/yr), after Ref. 21.

The residence time of carbon in all geological reservoirs is important because it controls the response of the lithosphere-climate system to perturbations in carbon fluxes, ${ }^{14}$ and long-term changes in the partitioning of oceanic carbonate may cause such perturbation. The key is that the fluid reservoirs (atmosphere, ocean, biosphere) contain so little carbon 


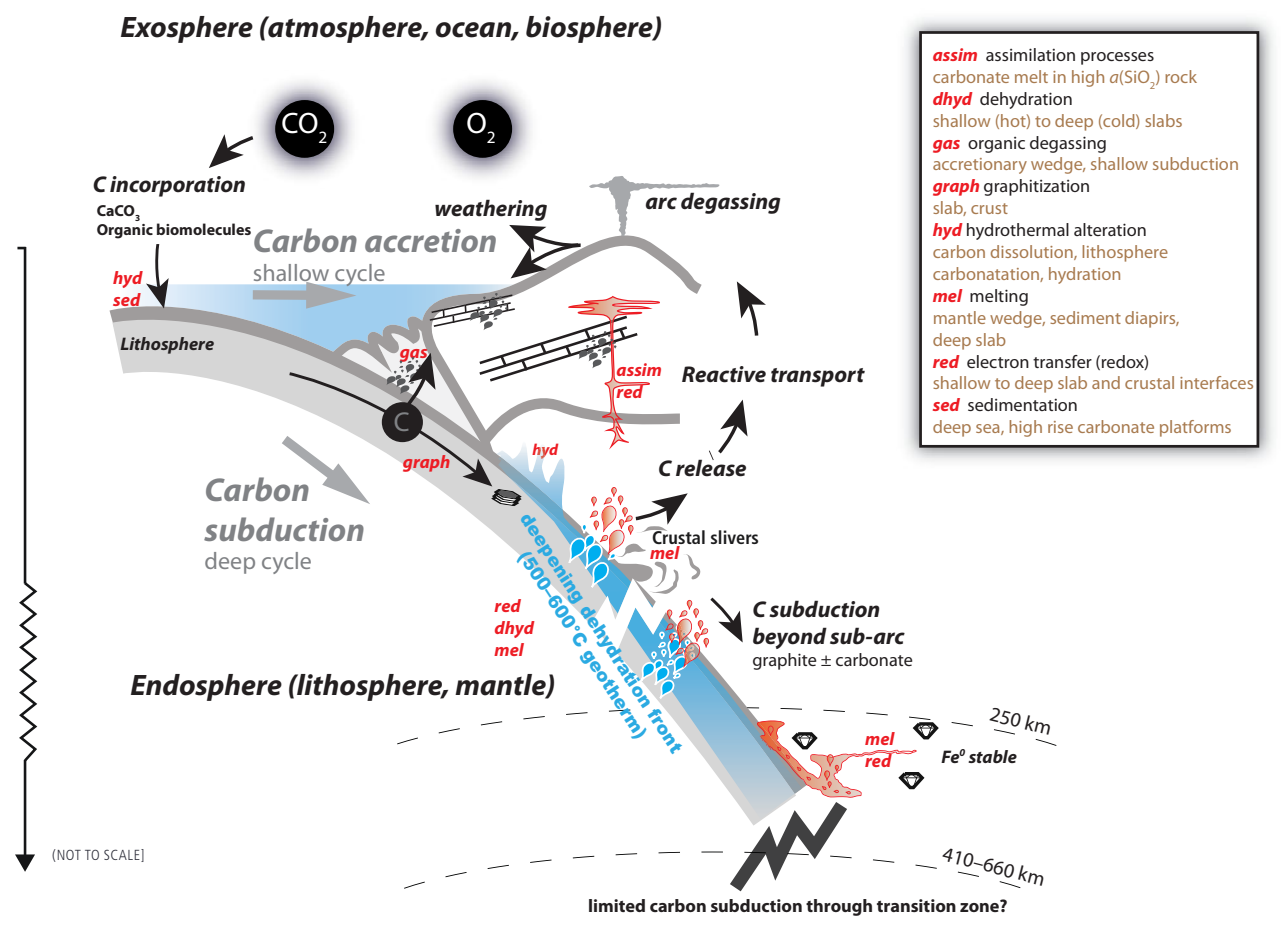

Figure 10.1 The major carbon (organic and inorganic) transformation pathways in subduction zones (layout adapted from Ref. 144). Processes that mediate these transformations are hydrothermal alteration - including reverse weathering - of the oceanic crust (seafloor), slab and mantle wedge (infiltration), sedimentation, diagenetic $\left(\mathrm{CO}_{2}\right)$ and catagenetic (e.g. $\left.\mathrm{CH}_{4}\right)$ degassing of kerogen, graphitization by pressure, temperature, and deformation, dehydration of slabs, electron transfers (redox) between Fe-, C-, and S-bearing mineral and liquids, melting, and reactive transport (assimilation/deposition) of C-bearing fluids and melts from slabs to the exosphere through mantle wedge and continental crust. Dehydration of slabs and partial melting are indicated by blue and red droplets, respectively. A potential limit to deep $\mathrm{C}$ subduction in the transition zone is indicated. ${ }^{84}$

that even slight perturbations of subduction or degassing fluxes may change the size of the surface carbon reservoir and impact climate and the diversity of surface habitats over timescales that are instants in the context of geological time. To the first order, the residence time of carbon in the subduction zone depends on the efficacy of shallow subduction processes $(<\sim 150 \mathrm{~km})$ to return carbon back to the atmosphere and ocean, and this can occur within timescales of $\sim 10 \mathrm{Myr}$ (Figure 10.1). The residence time of carbon in continents depends on the interaction/assimilation of continental carbon materials by arc magmas ${ }^{15,16}$ and on orogenic processes of continental $\mathrm{C}$ degassing. ${ }^{17,18}$

This contribution reviews the processes that transform and transport carbon materials in the subduction environment. We first introduce how surface and deep processes control the fluxes of carbon in and out of the solid Earth through subduction zones. Those fluxes define what we call the pace of the carbon cycle. Fast reorganization of Earth's separating and amalgamating tectonic blocks is responsible for episodic modifications of carbon 


\section{The tectonic carbon cycle, cross-scale architecture, and controls}

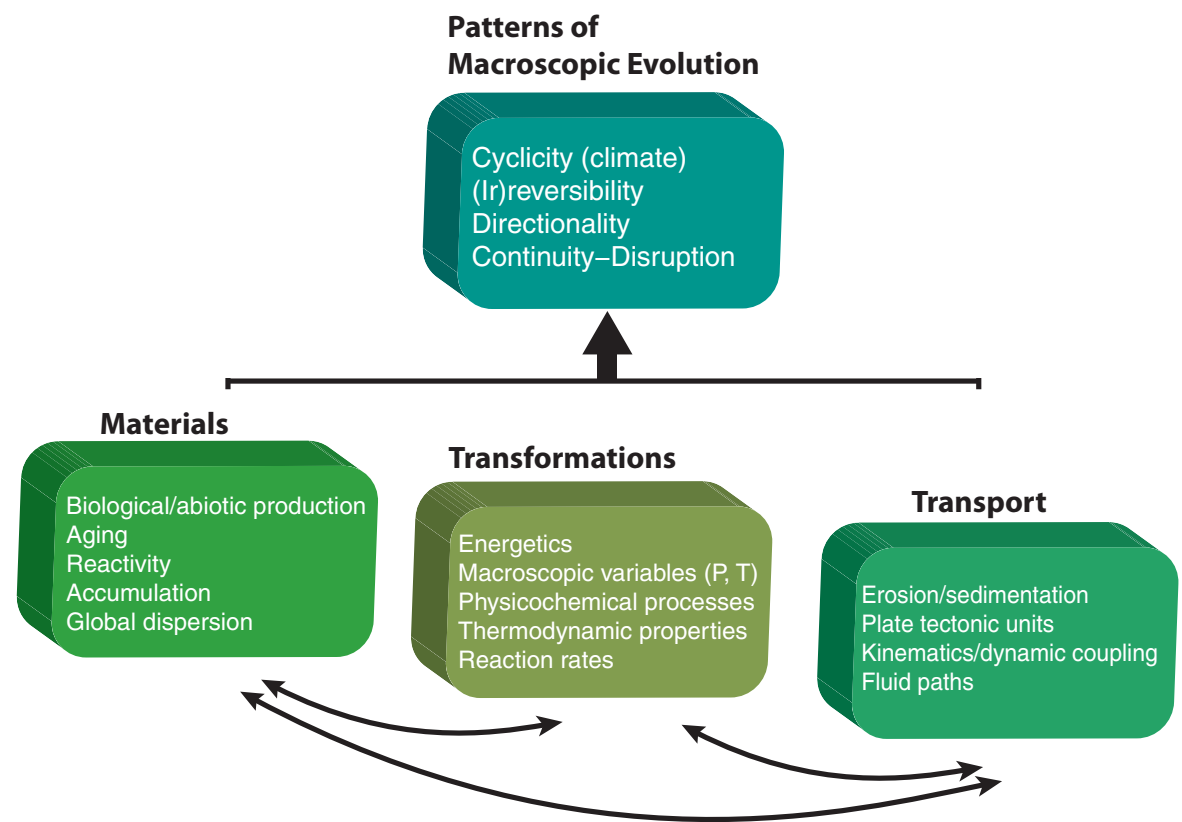

Figure 10.2 The tectonic carbon cycle is a hierarchical structure that must be studied at all scales of organization. The materials that comprise the carbon cycle and their transformations affect the higher levels of organization that transport carbon through the surface and deep Earth. In turn, the tectonic evolution of our planet influences the transformation of carbon-based geobiomaterials and the nature of the reactions that mediate those transformations. As a structure coproduced by biological and geological evolution, the subduction carbon cycle is the ideal research target to assess the link between the heterogeneity of Earth's materials, their reactivity, and the patterns of macroscopic evolution such as cyclicity, irreversibility, continuity, and disruption.

fluxes. We call these fluctuations the pulse, or cadence, of the carbon cycle. The carbon isotope record and other proxies ${ }^{19}$ suggest that the geological carbon cycle has been uninterrupted for more than 3 Gyr. We call this last property its longevity. Many recent advances illuminate the origin and controls of each of these central carbon cycle properties. Our work shows that only a cross-scale understanding in space and time will illuminate the links between the microscopic processes of the carbon cycle and patterns of macroscopic evolution, providing a toolkit to decipher the meaning of atmospheric signatures on Earth and other planets (Figure 10.2).

\subsection{How Do Surface Processes Control the Subduction Carbon Cycle?}

\subsubsection{Sources to Sinks and Back}

Subduction zones act both as a source and a sink of carbon for the exosphere. Over geological timescales, the source is the volcanic flux of carbon degassed in continental and 
oceanic arcs, while the sink is the carbon subducted in both reduced (organic C) and oxidized (carbonate) forms. But subduction fluxes do not depend on tectonic processes and mantle convection only; they are also controlled by surface processes driven by solar energy and tied to the water cycle. ${ }^{20}$ The overwhelming majority of carbon subducted is allochthonous, ${ }^{21}$ which means that most of it is added to marine sediments and the oceanic lithosphere from external sources - mainly the oceans and continents. The fate of carbon in subduction zones is therefore under tight oceanographic, biological, and geomorphic control (Figure 10.1), and it is especially sensitive to the partitioning of carbon between deep (pelagic) and shallow (e.g. shelves, oceanic plateaus) oceanic domains. ${ }^{22}$

There are three main carbon sinks, or pumps, that mediate the transfer of allochotonous carbon from oceans to sediment and the oceanic lithosphere: the hydrothermal carbon pump, which stores $\mathrm{CO}_{2}$ within the oceanic lithosphere during seafloor weathering; the soft-tissue pump, which leads to accumulation of soft organic tissues (of terrestrial or marine origins) in seafloor sediments; and the carbonate pump, which controls the topology of the carbonate compensation depth above which carbonate sedimentation on the seafloor may occur and below which carbonates are undersaturated and may lead to dissolution of old $\mathrm{CaCO}_{3}$ already deposited on the seafloor. ${ }^{23,24}$

\subsubsection{Heterogeneity of Sedimentary Carbonate Subduction (Carbonate Pump)}

Knowledge of carbonate heterogeneities on the seafloor and of carbon subduction rates mostly comes from recent decades of deep-sea drilling efforts. ${ }^{25}$ Continuous core sampling of sedimentary covers and upper oceanic crust offers a direct window onto what rocks may eventually subduct and degas. Today, most marine carbonates form and accumulate in the Atlantic and Indian Oceans, where few subduction zones have formed yet, and to a lesser degree on top of the ridges of the southeast Pacific. Estimates of total annual carbonate subduction range between 66 and $103 \mathrm{MtC} / \mathrm{yr}$ (Table 10.1), with about 60\% present in sediments ( 40-60 $\left.\mathrm{MtC} / \mathrm{yr}^{10,25,26}\right)$ and $40 \%$ in the altered oceanic lithosphere $(\sim 26-43 \mathrm{MtC} / \mathrm{yr}$ in basalts and serpentinites $\left.{ }^{21}\right)$. Carbonate subduction fluxes have been less than total carbonate deposition rates over the Cenozoic (Table 10.1), which suggests net accumulation of pelagic carbonate.

While efforts are underway to reduce these large uncertainties, the most important limitation for past and future predictions of carbon cycle dynamics is the heterogeneity of the flux (Figure 10.3): $25 \%$ of the global carbon subduction flux of the last $10 \mathrm{Myr}^{26}$ has occurred in the Sunda trench. The importance of the Indonesian hot spot, as well as those of the Aegean and Makran (Figure 10.3), contrasts with the western Pacific, where subduction and degassing fluxes are generally low. But the southern Pacific New Hebrides-SolomonVanuatu segment does not conform to this rule. Unlike most settings of the western Ring of Fire, the slab is young and plunges to the east. The system is long and so is rich in carbonate ${ }^{26}$ which it is a sizable contributor to the global subducted carbon inventory (Figure 10.2). Allard et al. ${ }^{12}$ showed that the Ambrym volcano in the Vanuatu islands pours out slab carbon at a record rate $(\sim 5-9 \%$ of the global volcanic carbon flux), providing a unique window onto the unusual $\mathrm{CO}_{2}$ productivity of this young arc system. ${ }^{27}$ 


\section{Heterogeneous Carbon Subduction in the Contemporary Ocean}

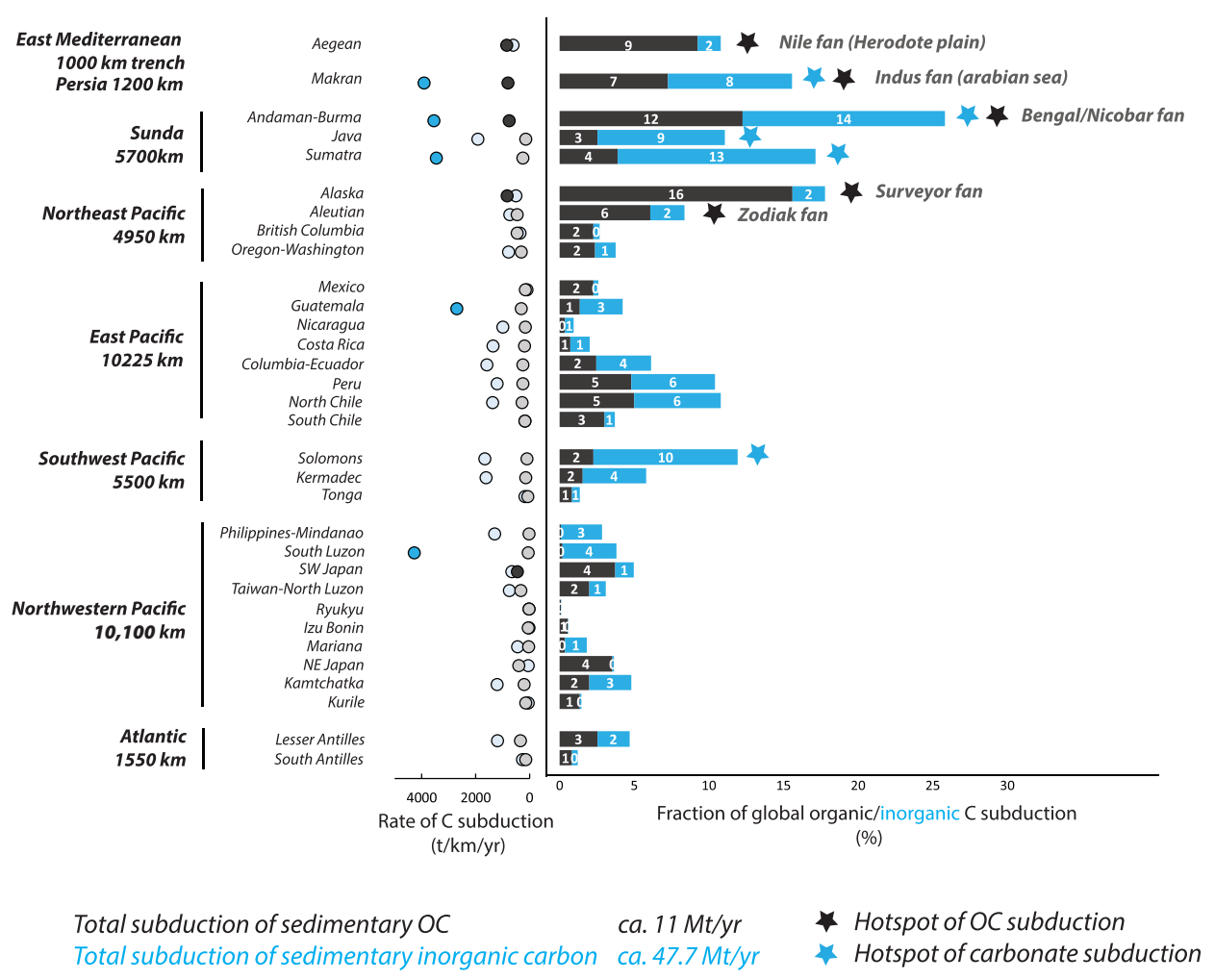

Figure 10.3 Contribution of selected subduction zones to global sedimentary C subduction flux. Fluxes are from Ref. 26, where length of subduction zones and carbon (organic and inorganic) concentrations in trench sediments are compiled (see also Ref. 25). Note that the computation of flux includes corrections for sediment porosity used but not reported in Ref. 26. Rate of carbon subduction are provided in $\mathrm{t} / \mathrm{km} / \mathrm{yr}$ for each subduction zone. Organic carbon is in gray and black, and black circles denote OC hot spots. Inorganic carbon is in pale and dark blue, with dark blue denoting hot spots. The fractional contribution of each subduction to the global sedimentary $\mathrm{C}$ flux is indicated as a percentage of total inorganic (blue) or organic (black) carbon subduction, respectively, in the histogram of the right panel (cf. Table 10.1). Note that the flux associated with basalt, gabbro, and ultramafic carbonate is not included. This corresponds to an additional subduction rate of $\sim 850 \pm$ $200 \mathrm{tC} / \mathrm{km} / \mathrm{yr}$.

\subsubsection{Hot Spot of Organic Carbon Subduction in the Sub-Arctic Pacific Rim (Soft Tissue Pump)}

A heterogeneous distribution and diversity characterize the soft tissue pump, ${ }^{28}$ as well as the subduction of organic carbon (OC). The burial of subductable OC in pelagic environments represents a flux of up to $10-30 \mathrm{MtC} / \mathrm{yr}$ over the last $150 \mathrm{kyr}$ (Figure 10.2), ${ }^{29}$ and perhaps during most of the Phanerozoic. ${ }^{2}$ Though modest compared to net primary 
productivity $(\sim 100 \mathrm{Gt} / \mathrm{yr}),{ }^{30}$ this weak but continuous isolation of organic reductants in sediments and rocks is essential for the persistence of atmospheric $\mathrm{O}_{2}$ levels that are so high and so far from thermodynamic equilibrium ${ }^{31}$ over geological timescales.

Just like carbonate, OC subduction is geographically heterogeneous, ${ }^{26}$ but its deposition hot spots are elsewhere (Figure 10.3). The trenches of Alaska, the Aleutians, and British Columbia contribute $\sim 23 \%$ of global OC subduction, while many other trenches, such as those of the western Pacific and Central America, are comparatively marginal. This is either because the trenches are small or because sediments do not contain much OC (Figure 10.2). This heterogeneity seems primarily controlled by continental erosion, weathering, and marine sedimentation rates. The northern Pacific hot spot is dominated by subduction of thick sequences of terrigenous sediments. ${ }^{32}$ Surprisingly, all OC subduction hot spots are associated with the subduction of deep-sea turbiditic sequences, such as Surveyor fan (Alaska) and Indus fan (Makran) (cf. Figure 10.3). The OC fraction derived from terrestrial sources (petrogenic and biologic ${ }^{33}$ ) can locally reach more than $70 \%$ in active margin sediments. ${ }^{34}$ This means that the geomorphic and climatic conditions that influence the export of organic-rich tropical, Arctic, and mountainous sediments ${ }^{35,36}$ to the marine environment ${ }^{37}$ are the same as those that control the pattern of OC subduction, too. Hence further research is needed to elucidate the link between continental configuration in the Wilson cycle, erosion/sedimentation patterns, and OC burial, with special attention paid to active margins. ${ }^{38}$

Unlike carbonates, which conserve their structure across a broad range of pressure and temperature conditions of Earth's interior, aging biomolecules display stunning plasticity in structure and composition ${ }^{39-41}$ acquired during transport and transformation through the lithosphere (Figure 10.2). It is often assumed that graphite is the main form of OC in rocks. However, organic macromolecules (e.g. kerogens) may not become proper crystalline graphite before the late stages of the subduction process (i.e. $>600^{\circ} \mathrm{C}$; Figure 10.1). The transformation of organic materials to their stable forms (e.g. graphite) involves a succession of metastable macromolecular intermediates called kerogens. ${ }^{42}$ Increasing temperature and the presence of water accelerates this process and drives the sequential release of $\mathrm{CO}_{2}$ (i.e. reduction of the kerogen residue) and then hydrocarbons (i.e. oxidation of the kerogens) from the kerogen residue in shallow, unconsolidated sediments ${ }^{43}$ and in accretionary wedges (Figure 10.1). ${ }^{44}$ This so-called carbonization ${ }^{42}$ may decrease the amount of OC effectively subducted by $20-40 \%$ or more depending on whether or not hydrocarbons are trapped within the descending slabs. This is still an open question.

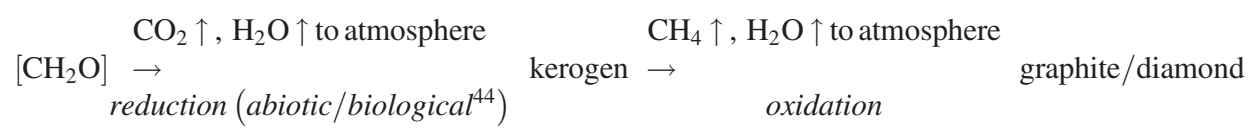

Subsequent collapse of the kerogen structure involves 3D ordering of the carbon-rich aromatic backbone and is favored by pressure and shear. ${ }^{45}$ This structural ordering is called graphitization (Figure 10.1). First-principles approaches are now shedding light on the 
microscopic pathways involved in this process. ${ }^{46,47}$ Because the transformations modeled by (10.1) are so slow in nature, it is even conceivable that the coldest slabs (e.g. the Mariana and the Aegean OC subduction hot spots) could reach the diamond stability field before completion of the carbonization and graphitization process. The graphitization process itself is irreversible, and field observations indicate that slabs may not lose much OC beyond $350-400^{\circ} \mathrm{C}^{48,49}$

The low reactivity of compact graphitic materials and their intricate weaving within poorly soluble mineral matrices explain why a graphitic fraction dislodged from rocks during erosion and weathering (18-104 ${\mathrm{MtC} / \mathrm{yr}^{33}}^{33}$ is continuously exported to the ocean (Figure 10.1). How much of this fossil petrogenic material subducts is not yet known, but it may represent $50 \%$ of OC in the trenches of South America. ${ }^{34}$

\subsubsection{An Ancient Hydrothermal Carbon Sink}

A last major contributor to allochthonous carbon incorporation to the oceanic lithosphere is hydrothermal carbonatization (Figure 10.1 and Table 10.1). ${ }^{50}$ More details are provided in a companion chapter in this book (Chapter 15). In short, the circulation of cold and carbonrich seawater through the oceanic crust and mantle dissolves cations from the oceanic lithosphere. Elevated concentrations of cations and rising temperature have been responsible for cycles of carbonate deposition in oceanic hydrothermal systems ${ }^{51}$ today and in the past. Occurrences of carbonatized basalts have been reported as early as in the early Archean Craton ${ }^{52}$ of eastern Pilbara (Australia) and in Archean greenstone belts. ${ }^{53}$ They suggest that: (1) carbonatization of the lithosphere may have been the means by which the atmosphere lost its primordial $\mathrm{CO}_{2}{ }^{54}$; and (2) carbonatization of the lithosphere may have been the only flux of global importance capable of balancing outputs from the deep Earth during the Archean, Proterozoic, and large swaths of the early Phanerozoic (Figure 10.1). Therefore, surface biogeochemical processes involving the water cycle may have controlled the magnitude and longevity of carbon inputs to subduction zones since their initiation, more than $3 \mathrm{Ga}^{55}$ The above shows that the pelagic reservoir is not at steady state over the Cenozoic. What about the subduction zone itself?

\subsection{Is the Subduction Zone Carbon Neutral?}

To the first order, the parameter that is most likely to affect models of atmosphere-climatelithosphere evolution over geological time $(<100 \mathrm{Myr})$ is the subduction efficiency, $\sigma$ (Figure 10.1). This macroscopic parameter is the fraction of subducted carbon that penetrates beyond sub-arc depths in subduction zones (cf. Figure 10.1). ${ }^{21,56}$ For a given subduction flux, the lower the parameter $\sigma$, the faster the response of the geological carbon cycle to perturbations in flux at the inlet of the subduction system.

Johnston et al. ${ }^{27}$ compared inventories of global input to and output from selected subduction zones to determine their efficiency. After correcting for possible mantle and 
continental contributions, ${ }^{16,57}$ Johnston et al. found that $18-70 \%^{21,26}$ of the input (Table 10.1) might be accounted for by arc carbon emissions derived from the slab, setting $\sigma$ to $\sim 0.3-0.8$. Corrections are needed because the accretionary and subduction cycles intersect when arc magma rises through the continental crust and that magma assimilates a fraction of the carbon that had been accreted to continents during previous collisional events (Figure 10.1). ${ }^{18}$ This phenomenon is thought to control the important emissions in Italy (e.g. Etna, Vesuvius), parts of the Andes, and Indonesia ${ }^{58}$ today. The estimates of Johnston et al. can be compared with estimates from Table 10.1, we find $\sigma$ of $\sim 0.4-0.9$. This is consistent, and it shows that a sizable fraction of subducted carbon does not take the short path out to the exosphere and continuously accumulates anywhere between the mantle wedge and the transition zone. The mismatch between input and volcanic output of slab carbon suggests that subduction zones, in their present configuration, act as a net sink of carbon over timescales of about 10-50 Myr.

But the meaning of a mismatch itself is unclear. Fundamentally, volcanic arcs are indicators of slab dehydration and partial melting in the mantle,${ }^{20,59}$ and the two processes are only indirectly linked to $\mathrm{C}$ loss from slabs. For example, dehydration at sub-arc depths for cool and cold slabs (e.g. Tonga, Mariana) drives increased fluid flux into the mantle wedge, producing higher degrees of partial melting and a greater proportion of carbon transport to the volcanic front (western Pacific). ${ }^{12}$ By contrast, hot and warm slabs promote carbon dissolution at shallower depths and may release carbon away from the volcanic fronts (e.g. Cascadia and Central America). Therefore, cooling of Earth is thought to have changed the pace of subduction carbon cycling ${ }^{14}$ slowly, over a billion-year timescale: a hotter Precambrian Earth would have returned more carbon faster from the carbonatized lithosphere, while cooler slabs that are denser and rich in garnet ${ }^{60}$ would promote penetration of carbonates to sub-arc depth and beyond.

This trend is only qualitative, and complementary approaches are required to quantify the fluxes and to assess their controlling factors. We take a broad-level look at three underlying mechanisms that control the partitioning of carbon between rocks and fluids in the most inaccessible parts of the subduction zones - the slab, mantle wedge, and arcs themselves: (1) the problem of carbon solubility in fluids and its underlying mineralogical controls; (2) the problem of fluid production within slabs; and (3) the problem of fluid reactivity along their paths from the subducted lithosphere to the surface.

\subsection{How Rocks Influence the Solubility of Carbon}

The composition of subducting slabs differs from that entering the subduction system. Open system processes - in which rocks are infiltrated by fluids and melts (also referred to indiscriminately as liquids) - control how much and how fast carbon is removed from slabs. The greater the amount of carbon released by dissolution and melting at fore- and sub-arc depths (Figure 10.1), the faster the subduction cycle may respond to any kind of perturbation in flux. Carbonates are the most abundant form of carbon in slabs (Table 10.1), 
and most box models of the geological carbon cycle ${ }^{61}$ represent the fate of carbonate by progress of the so-called reverse Urey reaction ${ }^{62}$ :

$$
\mathrm{CaCO}_{3}+\mathrm{SiO}_{2} \rightarrow \mathrm{CaSiO}_{3}+\mathrm{CO}_{2}
$$

However, this reaction is also a model, an aggregation of many processes. ${ }^{63}$ It is therefore not a mechanistic explanation of the dissolution process. The last decade has offered valuable insights into the microscopic complexity of Urey-type "decarbonation" reactions ${ }^{4}$ and their macroscopic expressions as carbon fluxes.

\subsubsection{Dissolution by Rising Pressure and Temperature: Which Silicate Is in Charge?}

An essential but implicit meaning of (10.2) is that the release of $\mathrm{C}$ from slabs is linked to that of water - the solvent and catalyst for the reaction. Carbon release tracks the main sequence of fore-arc and sub-arc mineral dehydration reactions. ${ }^{64}$ The most important of these reactions are the destabilization of lawsonite/epidote during eclogitization of the altered oceanic crust ${ }^{65}$ at $\sim 450-700^{\circ} \mathrm{C}$ and the dehydration of antigorite/chlorite ${ }^{66}$ in the serpentinized oceanic mantle. Both take place at around the same temperature, but the second pathway occurs deeper in the subduction zone because deserpentinization and dechloritization reactions occur in the altered ultramafic rocks of the lower and usually colder section of the descending slab (Figures 10.1 and 10.4).

Another insight from (10.2) is that the solubility of carbonates in hydrous fluids is primarily controlled by the relative stability of the various silicates (e.g. wollastonite, garnet $^{40}$ ) in which they transform; in other words, the rapid rise of C solubility at the onset of garnet formation in most sediment and mafic lithologies ${ }^{67}$ reflects the increasing relative stability of calc-silicates with rising temperature:

$\underset{(\mathrm{Ca}, \mathrm{Mg}, \mathrm{Mn}, \mathrm{Fe}) \mathrm{CO}_{3}}{\mathrm{M} \text { - carbonate }}+\underset{\text { quartz/lawsonite }}{(\mathrm{Al}) \text { silicate }}+\underset{\mathrm{H}_{2} \mathrm{O}}{\mathrm{H}_{2}} \underset{\mathrm{CaSiO}_{3} / \text { garnet }}{\text { solvent }} \rightarrow \begin{gathered}\mathrm{M}-(\mathrm{Al}) \text { silicated carbonic fluid }^{\mathrm{ss}} \\ \text { dissolved } \mathrm{CO}_{2}\end{gathered}$

This process is an incongruent dissolution, ${ }^{67}$ where $M$ is a divalent metal $\mathrm{Ca}, \mathrm{Mg}, \mathrm{Fe}$, or $\mathrm{Mn}$.

In practice, the congruent or incongruent nature of the dissolution depends on the kinetics of dissolution, the thermodynamic properties of calc-silicates, the kinetics of calc-silicate precipitation, and the rate of fluid transport. ${ }^{40,67}$ Recent thermodynamic analysis, however, suggest that congruent pathways may be restricted only to very high pressures and low temperatures ${ }^{67}$; regimes where fluid fluxes tend to be low. In addition, the ubiquitous presence of calc-silicates such as lawsonite down to $350^{\circ} \mathrm{C}$ in most silicic and aluminous lithologies ${ }^{68}$ supports the idea that their formation is not kinetically limited in the subduction zone. Hence, field and thermodynamic evidence suggests that incongruent pathways have been the most important in driving the dissolution of carbon along most subduction geotherms, today and in the geological past).

This general rule may not hold in the case of dolostone and limestone lithologies. These rocks usually lack the alumina and, in the most extreme case, silica that promote vigorous 


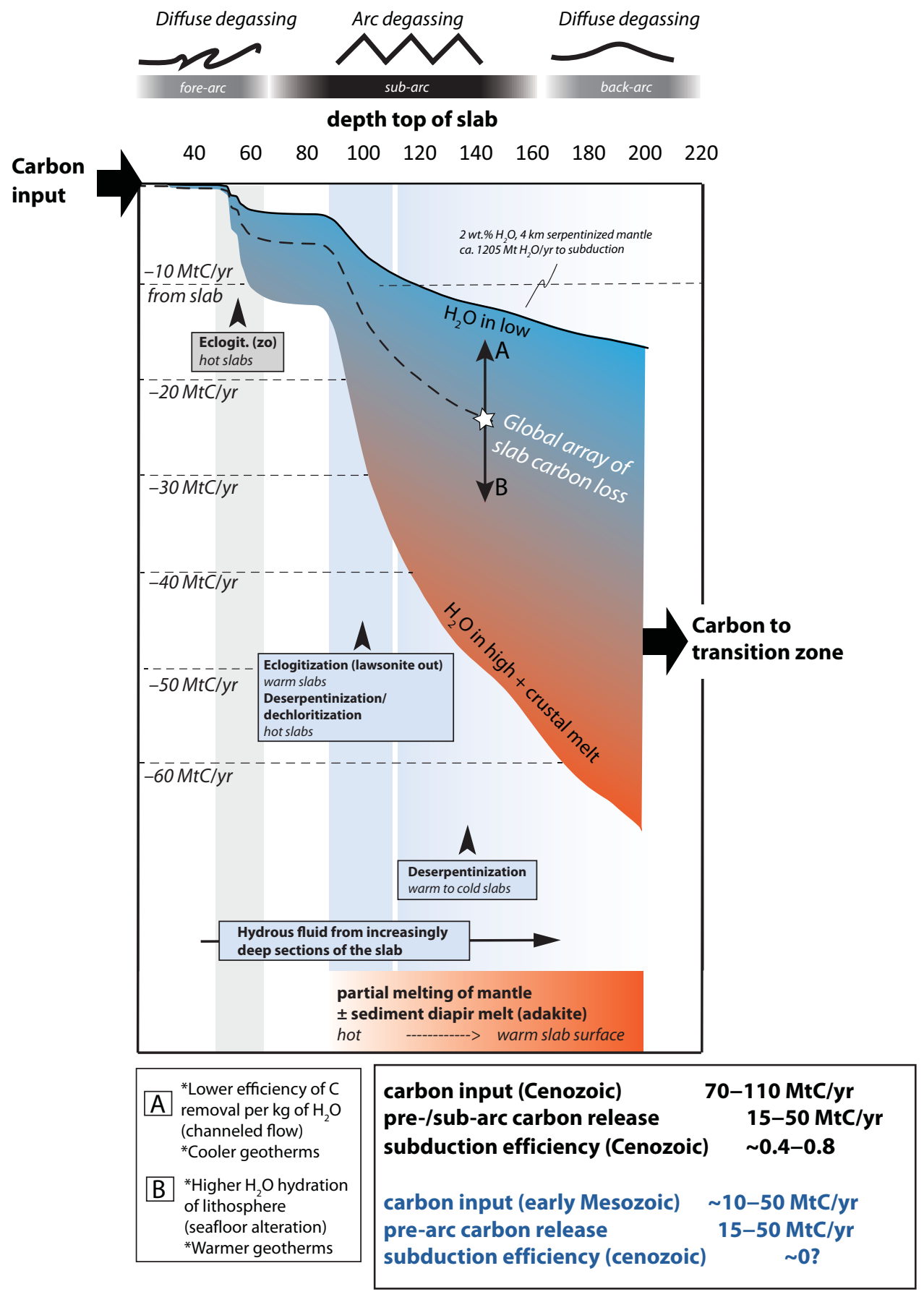

Figure 10.4 Devolatilization pattern $\left(\mathrm{H}_{2} \mathrm{O}\right.$ and $\left.\mathrm{C}\right)$ in a subducting slab and its link to subduction efficiency. The latter is the fraction of subducted carbon released at fore-arc and sub-arcs depths (cf. Ref. 3). The results are only qualitative and are based on ongoing studies investigating the coupling between $\mathrm{C}, \mathrm{H}, \mathrm{Na}, \mathrm{K}, \mathrm{Si}$, and $\mathrm{Al}$ cycles in open subduction-zone systems ${ }^{67}$ The shallow output flux depends on the hydration structure of the oceanic lithosphere, and conceivably, on the degree of partial melting (red tones). Overall, this flux varies between $\sim 15$ and $50 \mathrm{MtC} / \mathrm{yr}$ (i.e. in the order of magnitude of arc emissions ${ }^{21,27}$ ), between 0.1 and 0.6 of the incoming flux, and more likely $\sim 0.4-0.5$ in the Cenozoic (correspond to $\sigma$ of $\sim 0.5-0.6$; cf. Figures 10.6 and 10.7). This ratio may have approached 0 in the Paleozoic and Mesozoic (i.e. before the rise of pelagic calcifiers). This should be considered in long-term models of Phanerozoic carbon cycle evolution. 
dissolution (10.2 and 10.3). In addition, marble lithologies are also rather dry and also notably impermeable to fluid flow, and therefore not prone to dissolution. Yet dissolution reactions may also be sustained by chemical disequilibrium between contrasted lithologies even when pressure and temperature are invariant. For example, diffusion of volatiles $\left(\mathrm{H}_{2} \mathrm{O}^{69}\right.$ or $\left.\mathrm{H}_{2}{ }^{40}\right)$ and nonvolatile elements $\left(\mathrm{Al}\right.$ and $\left.\mathrm{Si}^{70}\right)$ into the marbles may modify $a$ $\left(\mathrm{CO}_{2}\right)$, or the stability of calc-silicates (10.2 and 10.3) and drive reactions (10.2) and (10.3). In fact, field evidence shows that when dissolution of marbles does occur, it tends to be restricted to the vicinity of fractures ${ }^{70}$ and tectonic discontinuities, ${ }^{69,71}$ precisely where fluids rich in $\mathrm{Al}$ and $\mathrm{Si}$ can circulate and boost carbon dissolution processes. Therefore, it is likely that incongruent pathways play the dominant role in carbon mobilization from slabs at subsolidus conditions. The growing importance of deep-sea carbonates (carbonate ooze $^{72}$ ) subduction in the next 100 million years (Table 10.1) makes them obvious targets for future research focusing on their peculiar mechanical properties and open-system behavior at elevated pressures and temperatures.

\subsubsection{Carbonate Melts from Hot Slabs and Diapirs?}

Partial melting of the slab may start at $>900^{\circ} \mathrm{C}$ in the presence of water. It can affect the top section of hot slabs (e.g. Aleutians/Mexico) when it is infiltrated by water, and it may also occur in unusually hot and buoyant fragments of slab sediments in the mantle wedge. ${ }^{73}$ The process forms ionic melts that are rich in carbonate components (i.e. hydrous carbonatites), ${ }^{74}$ but the thermodynamic, ${ }^{75}$ structural, ${ }^{76}$ and rheological properties of those compositionally heterogeneous melts remain largely unknown. Assessing their properties is important because carbonate melts are highly mobile, highly reactive, ${ }^{77}$ and important carriers of carbon beyond sub-arc depth anywhere between $\sim 100 \mathrm{~km}$ and 400-600 km within the slab and in the mantle wedge. A few implications follow:

(1) In carbonate bearing lithologies, formation of metamorphic garnet (e.g. grossular), the ubiquitous silicate mineral of high-pressure metamorphism, may be the most practical and important indicator of both dehydration ${ }^{78}$ and $\mathrm{C}$ redistribution (e.g. carbonate dissolution) between rocks and fluids via Urey-type processes (Figure 10.4).

(2) Carbon cycling in the slab is a problem of transport ${ }^{79}$ where dehydration, decarbonation, desilicification, and dealuminification of rocks are parts of a single overarching problem. ${ }^{67}$ Work is underway to link the microscopic properties of geo-fluids (aqueous, carbonate, silicate) and minerals with macroscopic patterns of element transport across shallow lithospheric reservoirs. ${ }^{48,67,80}$

(3) There is a growing consensus, informed by thermodynamic models, that pulses of carbon release from slabs by subsolidus dissolution do occur around $500-800^{\circ} \mathrm{C}$, representing an overall flux of between $\sim 10$ and $40 \mathrm{MtC} / \mathrm{yr}$ between $\sim 80$ and $140 \mathrm{~km}$ depth below the volcanic arc. ${ }^{48,81,82}$ This flux is uncertain, but overall it is consistent with volcanic emissions. ${ }^{21}$ The pulsatile character (Figure 10.4) of the flux, however, is primarily due to the timing and volume of $\mathrm{H}_{2} \mathrm{O}$ infiltration rather than to 
the thermodynamics, or kinetics, of the Urey-type reactions. This is important because it means that the subduction efficiency $\sigma$, as opposed to total carbon release, is controlled by where $\mathrm{H}_{2} \mathrm{O}$ is concentrated within the hydrated slab, rather than by the absolute amount of $\mathrm{H}_{2} \mathrm{O}$ contained in it. Only the water contained in the uppermost $10 \mathrm{~km}$ of slab mediates the fast cycling of carbon in the fore-arc and subarc regions.

(4) The parameter $\sigma$ may not be a mere parameter at all over geological timescales. It is more likely to be a variable that is dependent on the nature of carbon inputs. Indeed, we have shown that limestones and carbonatized lithosphere rocks behave differently, both mechanically and chemically. For example, while $\sigma$ of $\sim 0.4-0.8$ in the Cenozoic (Table 10.1) is characterized by important subduction of limestones (Table 10.1), this value may have vanished during most of the Precambrian, Paleozoic, and early Mesozoic, stranding carbon in shallow surface reservoirs. Interestingly, this idea is qualitatively consistent with recent isotopic and geochemical proxies, ${ }^{83}$ which suggest a net growth of the continental and pelagic carbonate reservoir (Table 10.1) over the last 2 Gyr. $^{2,83}$

\subsubsection{Where Is the Barrier to Deep Carbon Subduction?}

Global budgets are sensitive to thermal models and the permeability/rheology of rocks within the slab. Therefore, slabs that are cold and/or covered by thick and impermeable carbonate layers should retain a significant fraction of their carbon cargo to beyond sub-arc depths. What is the fate of carbon beyond this limit (Figure 10.1)?

If carbon makes it beyond sub-arc depths $(\sim 150 \mathrm{~km})$, it may not push much further beyond the transition zone $(\sim 410-660 \mathrm{~km})$. The reason for this is the existence of a deep depression in the temperature $\left(1000-1100^{\circ} \mathrm{C}\right)$ at which anhydrous carbonated oceanic crust melts at uppermost transition-zone conditions. ${ }^{84}$ Thomson et al. showed that the curvature of the solidus of carbonated eclogite is also controlled by the partitioning of nonvolatile elements, chief among them calcium and sodium, between mineral phases ${ }^{84}$ in highpressure eclogites. Most geotherms should intersect this melting barrier.

To the best of our knowledge, there is as yet no experiment that quantifies the effect of water on the topology of the anhydrous solidus of carbonated eclogites in the vicinity of the deep curvature (i.e. at the conditions of the transition zone around $\sim 10-20 \mathrm{GPa}$ ). Qualitatively at least, it is now undisputed that increasing activity of water $a\left(\mathrm{H}_{2} \mathrm{O}\right)$ dampens the solidus of carbonate rocks, ${ }^{74,85}$ bringing their temperature of melting closer to $900-1000^{\circ} \mathrm{C}$, promoting the formation of carbonate melts. This principle applies to carbonatized basaltic lithologies ${ }^{86}$ in particular and to all carbonate-bearing systems in general, typically those rich in iron and manganese ${ }^{87}$ that are relevant for the fate of subducted banded iron formation in the Archean Earth. This should limit even more the possibility of carbon subduction through the transition zone (Figure 10.1). 


\subsubsection{Are Thermal Anomalies the Norm?}

There is a growing consensus that the relevant pressure-temperature trajectories of slab materials may be hotter than most canonical models assume. ${ }^{81}$ First of all, there is an apparent incompatibility between slab thermal models predicted by theory ${ }^{88}$ - usually cold - versus those inferred from phase assemblage relations and mineral chemistry ${ }^{89}$ generally warmer. Second, the mantle wedge may be populated by detached fragments of slab sediments (e.g. diapirs ${ }^{73}$ ) that are thought to follow hotter pressure-temperature trajectories than the rest of the slab (Figure 10.1). It is important because it implies that the production of hydrous carbonatite melts may be more common than expected, particularly for cold slabs (e.g. Aegean) covered by kilometer-thick buoyant sedimentary piles. Overall, research into the thermal regime of slab materials may eventually redefine what thermal normality is in the subduction environment.

Taken together, the possibility of paths that are hotter than normal for most subducted sediments and the existence of a chemical barrier to deep carbonate subduction (Figure 10.1) means that most subducted carbon must have been stranded above the transition zone through most of Earth's history. ${ }^{21}$ However, there remain important uncertainties on the subduction efficiency, in particular, its variability in space and time. This uncertainty hinders quantitative understanding of the response dynamics of the carbon cycle to perturbations.

\subsection{Transport and Reactivity of Carbon-Bearing Liquids}

Aqueous fluids and carbonatitic melts produced in the slab are predicted to be mobile due to their low viscosity. But crustal liquids are not passive carriers of carbon back to the surface. They re-equilibrate continuously with changing environmental conditions across the crust and mantle. Both carbonate and elemental C (graphite/diamond) may form along the way and delay the return of subducted $\mathrm{C}$ to the exogenic cycles. It may take anywhere from thousands to millions of years for the mobilized carbon to return to the exosphere.

Transport of fluids and melts occurs mostly along lithological interfaces and other discontinuities, such as faults and fractures (see Figure 10.4 and Supplementary Materials at the end of chapter) in the heterogeneous interface between slab and mantle, ${ }^{90}$ and within the rocky mantle itself. ${ }^{64}$ This is observed in the field ${ }^{71}$ and via geophysical observations of fluid migration through the mantle wedge. ${ }^{91}$ The fate of C-bearing liquids during their ascent through the slab, mantle wedge, and overriding crust is controlled by four critical variables: pressure/temperature, redox state, activity of silica, and activity of water.

\subsubsection{Pressure and Temperature}

For the same reason that rising pressure and temperature enhances the solubility of carbonates in subducting slabs, downward temperature paths, too, may lead to carbonate precipitation out of fluids ascending along and across the slab. This chromatographic 
process is predicted thermodynamically ${ }^{69}$ and is observed in the field. ${ }^{92}$ This illustrates that there is a delay between the time carbon is dissolved from the slab and the time it eventually reaches the surface.

\subsubsection{Low- and High-Temperature Redox Processes}

The redox state, too, is important for the fate of both carbonates and organic materials, and it is usually measured by the thermodynamic activity of oxygen. Carbon can bond to both oxygen and hydrogen, and the balance between oxygenated species (e.g. $\mathrm{CO}_{2}$ ) and hydrogenated carbon species (e.g. $\mathrm{CH}_{4}$ ) in a fluid-rock system depends on the nature and abundance of other "redox" elements in the rock, such as $\mathrm{Fe}\left(\mathrm{Fe}^{2+}, \mathrm{Fe}^{3+}\right), \mathrm{Mn}$, and multiple $\mathrm{S}$ species susceptible to exchanging electrons with carbon. ${ }^{93}$ But there is a limit to the amount of $\mathrm{C}$ a fluid can contain at typical subduction-zone conditions. This limit is fixed by thermodynamics, and varies with pressure, temperature, and rock composition. ${ }^{67,94}$ If graphitic materials are stable - as is usually the case in subducted sediment (Figure 10.4) then the so-called graphite-saturated $\mathrm{COH}$ system imposes a minimum in carbon solubility midway between fluids dominated by $\mathrm{CO}_{2}$ and fluids dominated by $\mathrm{CH}_{4} \cdot{ }^{94}$ The existence of such a minimum is important because it implies that quasi-static changes in pressure, temperature, $a\left(\mathrm{H}_{2} \mathrm{O}\right)$, or $f \mathrm{O}_{2}$ of a graphite- or diamond-saturated fluid could involve both carbon dissolution and/or precipitation of the fluid. Therefore, $\mathrm{C}$ may be locked in the form of graphite during fluid ascent through the slab $^{40,95}$ or through the continental crust, ${ }^{96,97}$ creating complex locking and unlocking pathways for deep carbon (Figure 10.5).

Fluctuations in redox conditions may occur anywhere from the shallow to the deep subduction zone. For example, it has been shown that serpentinite assemblages maintain their reducing power in the shallow subduction zone at conditions lower than $10 \mathrm{kbar}$ and

(a)

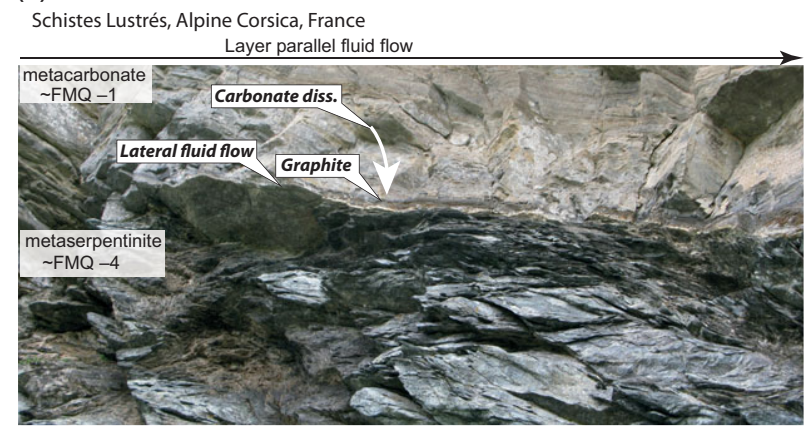

(b)

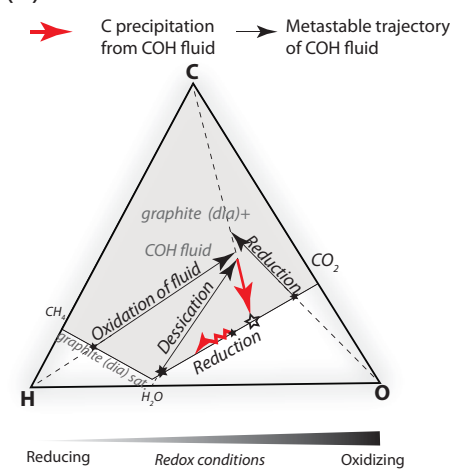

Figure 10.5 Redox pathways in the subduction zone. Graphite precipitation from carbonate at a lithological interface. (a) Field image of the outcrop in Alpine Corsica. ${ }^{40}$ (b) Representative $\mathrm{COH}$ diagram showing the curvature of the $\mathrm{C}$-saturation surface at the elevated pressures and temperatures typical of subduction zones, illustrating various pathways leading to elemental carbon precipitation. 
$500^{\circ} \mathrm{C}^{98}$ Those conditions may cause the spontaneous formation of refractory graphite from carbonate according to:

$$
\underset{(\text { carb })}{\mathrm{CO}_{2}}+\underset{(\text { mag } / \text { serp })}{4 \mathrm{FeO}}=\underset{(\text { garnet })}{2 \mathrm{Fe}_{2} \mathrm{O}_{3}}+\underset{\text { (graphite })}{\mathrm{C}^{0}} .
$$

There is now evidence for such a mechanism occurring at temperatures of no more than $450^{\circ} \mathrm{C}$ (Figure 10.4). ${ }^{40,71}$ A redox mechanism formally analogous to (10.4) is thought to occur below $250 \mathrm{~km}$, too, where carbonatite melts expelled from the slab re-equilibrate with mantle lithologies where metallic iron is stable (Figure 10.1). ${ }^{99}$ Mutual reequilibration between carbonatite melts and mantle rocks involves the spontaneous production of diamond according to:

$$
\underset{(\text { melt })}{\mathrm{MgCO}_{3}}+\underset{\text { (metallic iron) }}{2 \mathrm{Fe}^{0}}=\underset{\text { (iron oxide) }}{\left(\mathrm{Mg}_{0.33}, \mathrm{Fe}^{2+}{ }_{0.67}\right) \mathrm{O}}+\underset{\text { (diamond) })}{\mathrm{C}^{0}} .
$$

\subsection{3 $\mathrm{SiO}_{2}$ Activity}

Just like $a\left(\mathrm{SiO}_{2}\right)$ influences the dissolution of $\mathrm{C}$ in hydrous fluids of slabs via Urey-type reactions (cf. (10.2) and (10.3)), fluctuations of $a\left(\mathrm{SiO}_{2}\right)$ impact the behavior of $\mathrm{C}$ in all types of subduction-zone liquid in which it may dissolve. This is particularly true of carbonate and other alkaline melts. Experimental works ${ }^{77,100}$ have shown that dolomitic melts formed in the descending slab degas at the contact of peridotitic mineral assemblages characterized by comparatively higher $a\left(\mathrm{SiO}_{2}\right)$ (orthopyroxene and clinopyroxene).

$\begin{aligned} & 2 \mathrm{CO}_{3}{ }^{2-\text { melt }} \\ & \text { base (carbonatitc melt) }\end{aligned}+\begin{aligned} & \mathrm{SiO}_{2}{ }^{\text {rock }} \\ & \text { acid (mantle rock) }\end{aligned} \quad \begin{aligned} & \mathrm{SiO}_{4}{ }^{4-, \text { melt }} \\ & \text { base (carbonatitic melt) }\end{aligned} \quad \begin{aligned} & 2 \mathrm{CO}_{2}{ }^{\text {gas }} \\ & \text { acid (mantle gas) }\end{aligned}$.

This mechanism may supply large fluxes of diffuse $\mathrm{CO}_{2}$ outgassing with decompression, as the melt dissolves more silica or any other acidic component. Therefore, cataclysmic eruptions (kimberlites ${ }^{101}$ ) may ensue if those melts stall for long periods of time ${ }^{1}$ in environments such as the base of the continental crust.

\subsubsection{Water}

Just like surface processes, many processes of the slab-mantle wedge interface involve repeated cycles of fluid desiccation, whereby fast and near-quantitative redistribution of $\mathrm{H}_{2} \mathrm{O}$ from fluids toward solid (e.g. mantle wedge serpentinization) or melt phases occurs. Desiccation is a possibly dominant mode of elemental carbon sequestration in the crust and upper mantle, although this mechanism has received little attention so far. Because the solubility of water in silicate melts that are poor in alkalis is greater than that of carbonic species, ${ }^{102,103}$ rehydration (below $600^{\circ} \mathrm{C}^{104}$ ) and flux melting of the mantle wedge by infiltrating $\mathrm{COH}$ fluids may form restitic graphite/diamond (Figure 10.5b) via: 


$$
\text { reactant }{ }^{\text {rock }}+\mathrm{C}\left(\mathrm{H}_{2} \mathrm{O}\right)^{\text {fld }}=\text { residue } \mathrm{C}^{\text {gph } / \text { dia }}+\text { solid } / \text { melt } \cdot \mathrm{H}_{2} \mathrm{O} \text {. }
$$

This mechanism is supported by theory (Figure 10.5); evidence for it in nature may be found in the Kokshetav massif (north Kazakhstan) ${ }^{105}$ or in Lianoning (northeast China), ${ }^{106}$ where the association of graphite with jadeites is intriguing.

Overall, a combination of physicochemical processes drive not only carbon loss from slabs, but also its reactivity and fate in the heterogeneous chromatographic columns that separate slab liquids from the surface. Therefore, a carbon flux at the surface of Earth (or of any planet) does not mean an active release is operating.

\subsection{Carbon Dynamics at the Subduction/Collision Transition}

Surface, subduction, and mantle processes control the fluxes of C. But numerous past instances of climatic and carbon cycle perturbations ${ }^{107}$ show that changes in geological fluxes occur continuously on Earth. Subduction zones evolve, may change polarity, ${ }^{108}$ and even vanish in complex collision zones. The subduction/collision transition ${ }^{109}$ illustrates how quickly the reorganization of Earth's tectonic building blocks may cause imbalances in the geological C cycle (Figure 10.5). We refer to these episodic changes as the pulse of the carbon cycle.

The collision zone ${ }^{110}$ is a dominant pathway of carbon processing, ${ }^{111}$ particularly in the Indo-Pacific region today (Ontong Java in the Vanuatu-Solomon arc) and in the former Tethyan orogens. ${ }^{112,113}$ Docking of Greater India to Eurasia caused a situation of geodynamic instability marked by the Himalayan orogeny (Figure 10.6) that lasted for at least $50 \mathrm{My}^{113}$ and is still going on today at a reduced pace. Are the Himalayas carbon neutral over a geological timescale ${ }^{114}$ This is a question of timescales.

On geological timescales, early workers proposed that the Tethyan orogeny as a whole would operate as a $\mathrm{CO}_{2}$ sink. The sink is due to enhanced silicate weathering ${ }^{115}$ of freshly exhumed rocks and is usually modeled by the forward Urey-Ebelmen ${ }^{4}$ reaction (cf. (10.2)):

$$
\mathrm{CaSiO}_{3}+\mathrm{CO}_{2} \rightarrow \mathrm{CaCO}_{3}+\mathrm{SiO}_{2} .
$$

Recent studies provide insights into the complexity of this problem. Enhanced erosion, biotic OC burial, ${ }^{116}$ and accretion of pelagic carbonates to the growing orogen ${ }^{112}$ operate as long-term $\mathrm{CO}_{2}$ sinks, while the weathering of petrogenic $\mathrm{OC}^{117}$ and enhanced sulfide weathering ${ }^{118}$ counteract $\mathrm{CO}_{2}$ sources, at least transiently, ${ }^{118}$ in much the same way as the interaction of orogenic magma with accreted carbonates ${ }^{16}$ or $\mathrm{OC}^{119}$ in continents do (Figures 10.1 and 10.6). It is not at all clear how the acceleration of phosphorus and other nutrients exported to the marine basins surrounding the Himalayan orogen boosted net primary productivity, at least locally (i.e. another $\mathrm{CO}_{2}$ sink). The inventory and relevant timescales of these processes - surface or deep - are crucial to establishing a thorough carbon budget for an orogeny over geological timescales.

As part of this inventory effort, we propose that focusing on the orogen itself may still miss an entire - deeper - dimension of the tectonic disequilibrium caused by collision. 


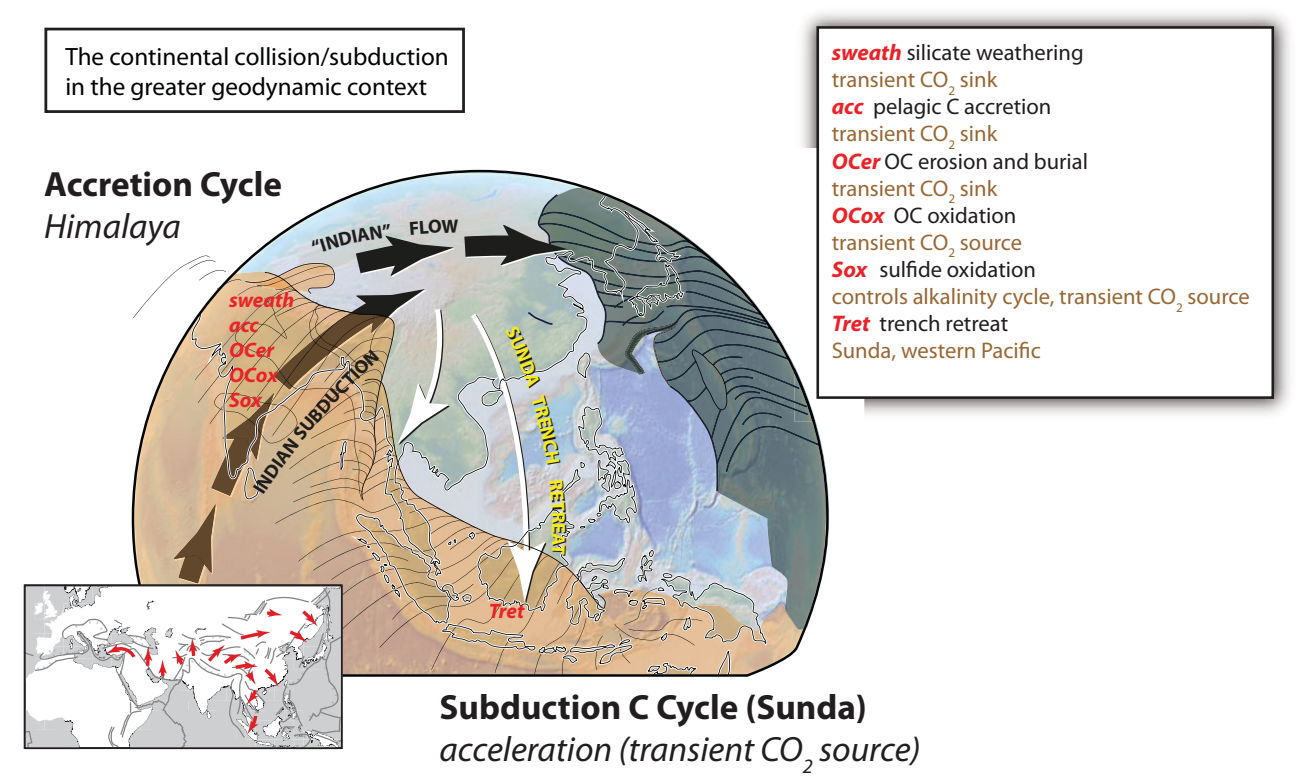

Figure 10.6 Examples of tectonic complexity at subduction zones: the collision factory. Long-range kinematic and dynamic reorganization in the western Pacific and Sundaland triggered by greater India subduction and collision; modified from Ref. 147. The carbon budget of the collision zone ${ }^{114}$ may only be resolved at the mesoscale (i.e. one that includes the orogen itself and the evolving subduction zones in its broad periphery).

Figure 10.6 shows how the collision of India with Eurasia since the Eocene involved largescale coupling between continent-continent collision and slab subduction in the western Pacific and Southeast Asia (Sunda trench). The southeast-ward motion of lithospheric fragments of Eurasia was accommodated by lithospheric and asthenospheric reorganization east of the collision zone. ${ }^{120}$ As a consequence, continental subduction and collision to the north have been accompanied by extension tectonics distributed over a 3000-km region across the Sunda plate and western Pacific starting 45 Myr ago. ${ }^{121} \mathrm{We}$ propose that slab retreat and rollback over this extended area may have boosted the pre-collisional $\mathrm{CO}_{2}$ source associated with the Sunda and western Pacific subductions, partly compensating for the sinks linked to the growing orogen itself. The mechanisms involved in a subduction acceleration are illustrated in the model of Section 10.7.

The result of tectonic and biological coevolution over the Cenozoic is one of long-term cooling, with a thermal maximum at the onset of the collision. Today, atmospheric $\mathrm{CO}_{2}$ is at a record low level, and the pace of the pre-anthropic subduction carbon cycle has reached a kinetic minimum. ${ }^{122}$ Antarctica and Greenland ice sheets grew over the last $\sim 30-40$ My. Degassing of the pelagic carbonates that have subducted beyond sub-arc depths over the Cenozoic and enhancements in pelagic sediment subduction in the future may boost the pace of the non-anthropogenic carbon cycle sometime in the next $100 \mathrm{Myr}$. 


\subsection{A Flavor of Life: A 3 Billion-Year-Old Record}

The biosphere and geosphere are not separate entities. They are bound by the electron (redox) and proton (acid-base) transfer reactions of biological metabolism. Therefore, while Earth is the scaffold of biological evolution, the evolving style and longevity of the subduction-zone carbon cycle are in various ways indirect products of biological evolution (Figure 10.7). Four main milestones of this coevolution were: (1) the origin of cell death; (2) the evolution of the photosynthetic water-splitting complex; (3) the rise of multicellular algae and land plants; and (4) the advent of carbonate biomineralization. Life altered the geological cycle of electrons about 2.5 billion years ago and then the geological cycle of alkalinity, in the beginning indirectly, and then more directly.

\subsubsection{Biological Evolution Influences Carbon Subduction: First Milestone}

Genomic studies ${ }^{123}$ and isotopic proxies ${ }^{19}$ place the origin of autotrophic life and respiration - the main carbon source and sink today - at some time in the Archean, but life alone did not affect the geological cycle of carbon as much as mortality did. Viral lysis of prokaryotes ${ }^{124,125}$ and, possibly, genetically encoded death pathways ${ }^{124}$ may have played a disproportionate role in driving prokaryote mortality and, therefore, a primordial soft-tissue pump that helped the early biological necromass to spread across all marine habitats, including trenches and subduction zones. The ancestral origin of viruses ${ }^{126}$ is at least qualitatively consistent with the idea that a sustained flux of dead organic materials from the sunlit upper ocean to the marine sediments may have been established at some time in the Archean. While it is conceivable that carbonatization of the oceanic crust, and its subduction, had been in place ever since oceans and the oceanic crust coexisted, it is the marine accumulation, isolation, accretion, and subduction ${ }^{127,128}$ of organic reductants that sparked an OC cycle that was truly geological in scale.

$$
\mathrm{CO}_{2}+\text { reductant } \rightarrow \mathrm{C}_{\text {org }}+\text { oxidants. }
$$

\subsubsection{Biological Evolution Influences the Dioxygen Cycle: Second Milestone}

About 2.4 Gyr ago, the accumulation of OC in sediments, continents, and the mantle through subduction zones ${ }^{128}$ became, for the first time, tied to the production and eventual accumulation (about $2.33 \mathrm{Ga})^{2}$ of dioxygen gas in the lithosphere (in the form of iron oxides) and then in the exosphere. ${ }^{129}$ The evolution of the water-splitting system ${ }^{130}$ exploited, for the first time, the abundance of the water molecule as an almost unlimited source of protons and electrons for photosynthesis, releasing $\mathrm{O}_{2}$ as a highly reactive waste product. ${ }^{131}$

$$
\mathrm{H}_{2} \mathrm{O} \rightarrow 4 \mathrm{e}^{-}+4 \mathrm{H}^{+}+\mathrm{O}_{2} .
$$

This redox pathway enhanced the stability of atmospheric $\mathrm{CO}_{2}$ (causing major glaciation, Figure 10.7), acidified riverine waters, ${ }^{132}$ and therefore may have boosted the weathering flux 


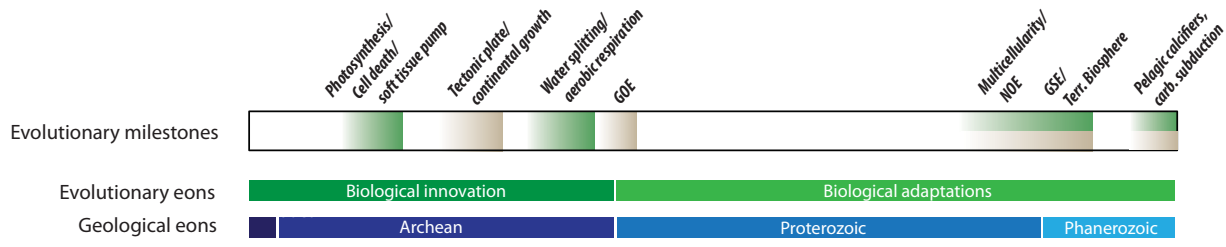

eological eons

Progressive oxygenation of atmosphere, surface oceans, and deep oceans

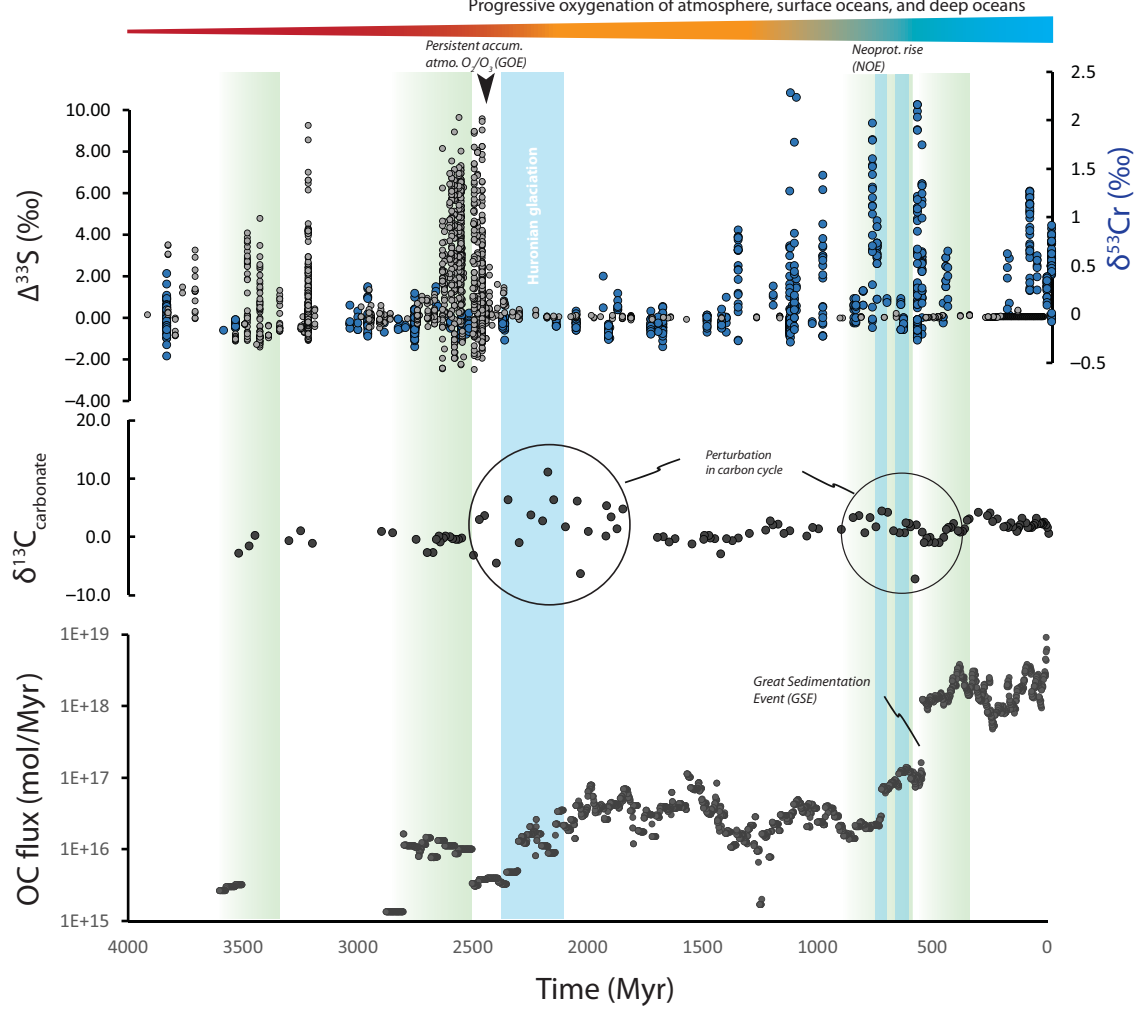

Figure 10.7 Milestones in the coevolution of life, the surface environment, and the tectonic carbon cycle (see also Figure 10.2). The eons of biological innovations and adaptations are from Ref. 131. Green tones denote biological transitions, blue tones denote geological transitions. (Upper Graph) The rise of atmospheric ozone and oxygen $\left(\Delta^{33} \mathrm{~S}\right.$ proxy $\left.{ }^{148}\right)$, the meso/neoproterozoic rise of oxygen $\left(\delta^{56} \mathrm{Cr}\right.$ proxy $\left.{ }^{149,150}\right)$, the evolution of bryophytes and vascular plants, and the evolution of pelagic calcifiers are highlighted (adapted from Ref. 151). (Middle Graph) Statistical reconstruction of the carbonate isotope $\left(\delta^{13} \mathrm{C}_{\text {carbonate }}\right)$ record through time. ${ }^{19}$ (Lower Graph) The statistical reconstruction of the global OC burial flux reconstructed from the North American sedimentary record from Ref. 37 is also appended. Note that the sharp increase in OC burial flux at the "great unconformity"138 that marks an order of magnitude rise in continental weathering and sedimentation through the early Paleozoic. GOE $=$ Great Oxygenation Event $\mathrm{NOE}=$ Neoproterozoic Oxygenation Event. 
of essential nutrients (e.g. trace elements, phosphorus, etc. ${ }^{133}$ ) from proto-continents to oceans. Life, therefore, exerted its first indirect control of the cycle of alkalinity and caused large-scale perturbations in the carbon cycle (Figure 10.7). A more subtle effect of this gradual redox shift was that it contributed to locking water on Earth, instead of water slowly escaping into space ${ }^{134}$ as it did on Venus. ${ }^{135}$ This is important because water drives and lubricates the subductionzone system and, through it, the entire carbon cycle. Therefore, the rise of redox disequilibrium between the fluid and solid compartments of Earth may have laid the ground for the exceptional longevity and vigor of Earth's subduction carbon cycle.

\subsubsection{Biological Evolution Influences the Cycle of Alkalinity: Third Milestone}

About 1.5 billion years later, the biosphere enhanced its control on the geological cycle of alkalinity. The invasion of continents by algae and plants with roots in the early Paleozoic enhanced erosion and continental weathering. ${ }^{136,137}$ Enhanced sediment export to the ocean boosted marine sedimentation of OC (Figure 10.7), ${ }^{37,138,139}$ yet another potential process feeding back into the subduction carbon cycle.

\subsubsection{Alkalinity Feeding Back into Biological Evolution: Fourth Milestone}

The rising flux of dissolved weathering products (e.g. Ca) may have promoted further biological innovations. The geological record suggests algae evolved new ways to exploit the carbonate oversaturation state of the oceans over the Mesozoic. ${ }^{140}$ By accelerating chemical reactions, these organisms were able to reroute excess oceanic alkalinity to the carbonate skeleton and ultimately to rocks. The expansion of calcifiers to the distal parts of the oceans over the last 150 Myr boosted deep seafloor carbonate deposition and subduction. Therefore, the idea that a clear-cut dichotomy separates Earth's biological processes (dominated by redox processes) and abiotic geochemical reactions (dominated by proton transfer chemistry) ${ }^{141}$ does not hold in the context of geological time (Figure 10.2). Fascinatingly, much of the biotic carbonate of the Atlantic and Indian oceans has yet to be subducted; when will the Atlantic Ring of Fire form? We do not know.

\subsubsection{Response of Climate to the Enhanced Subduction of Pelagic Carbonates}

The geological response to pelagic calcifiers is still very much ahead of us. The models of Figures 10.6 and 10.7 illustrate potential scenarios and the timescales involved. They illustrate how subduction zones are components of a larger dynamic system that includes continents, oceans, and biosphere. Figure 10.8 is simplistic, and it builds on much previous work $^{3,8}$; details are provided in the Supplementary Online Materials.

We focus on the geological response of the carbonate cycle and atmospheric temperature to modifications in key geodynamic or biological parameters: $\beta$, the partitioning of carbonate between the pelagic and continental (accretion) environment; $\sigma$, the fraction of 
(a) Subduction Cycle

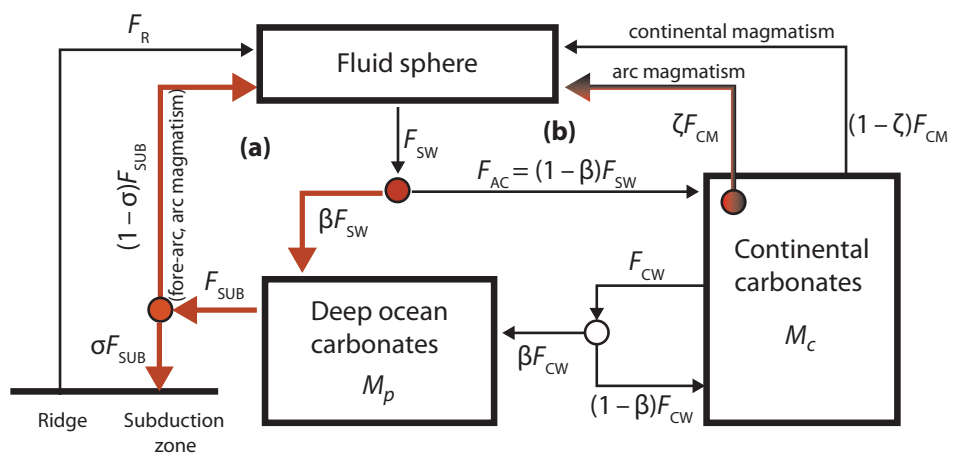

Figure 10.8 Non-steady-state response of the carbonate cycle to geodynamic and biological forcing: model design. The pelagic $\left(M_{\mathrm{p}}\right)$ and continental $\left(M_{\mathrm{c}}\right)$ carbonate reservoirs evolve by exchange of $\mathrm{C}$ (i.e. fluxes $F_{\mathrm{i}}$ ) with the atmosphere and mantle (Figure 10.6). Mantle is assumed to be a reservoir of infinite residence time. The silicate weathering flux $F_{\mathrm{sw}}$ is linked to atmospheric temperature by a simple polynomial relation from Ref. 61. The C fluxes $F_{\mathrm{i}}$ are linked to $M_{\mathrm{i}}$ via rate constants $k_{\mathrm{i}}$ (e.g. $F_{\mathrm{cm}}=k_{\mathrm{cm}} M_{\mathrm{c}}$, and $\left.F_{\text {sub }}=k_{\mathrm{sub}} M_{\mathrm{p}}\right)$. The initial steady state is obtained with starting conditions chosen and updated from Ref. 3 to be consistent with present-day values for $\mathrm{C}$ fluxes and reservoir sizes: $F_{\mathrm{i}}=3 \mathrm{Tmol} / \mathrm{yr}, F_{\mathrm{sw}, \mathrm{i}}=10 \mathrm{Tmol} / \mathrm{yr}($ Ref. 152$) ; F_{\mathrm{cw}, \mathrm{i}}=15 \mathrm{Tmol} / \mathrm{yr}$ (Ref. 152); $k_{\mathrm{cm}}=0.00035$, $k_{\text {sub }}=0.0072, M_{\mathrm{c}, \mathrm{i}}=7.583 \times 10^{21} \mathrm{~mol}^{83}{ }^{83} M_{\mathrm{p}, \mathrm{i}}=0.917 \times 10^{21} \mathrm{~mol},{ }^{83} \sigma=0.6$ (see above), $\beta=0.25,{ }^{3}$ $\zeta=0$. The system is solved analytically to find its steady state, which is close to present-day condition (i.e. $M_{\mathrm{c}}=7.909 \times 10^{21} \mathrm{~mol}$ (residence time $\tau_{\mathrm{c}} \approx 2800 \mathrm{Myr}$ ); $M_{\mathrm{p}}=0.810 \times 10^{21} \mathrm{~mol}$ (residence time $\tau_{\mathrm{p}} \approx 140 \mathrm{Myr}$ ); cf. Supplementary Online Materials). This steady state is then used for perturbation analysis (Figure 10.7).

subducted carbon transported beyond sub-arc depths (Figure 10.3); and $\zeta$, a selfamplification factor corresponding to the fraction of continental carbonate degassing that is controlled by arc magmatism. The pelagic $\left(M_{\mathrm{p}}\right)$ and continental $\left(M_{\mathrm{c}}\right)$ carbonate reservoirs evolve by exchange of $\mathrm{C}$ (fluxes $F_{\mathrm{i}}$ ) with the atmosphere and mantle (Figure 10.6). The silicate weathering flux $F_{\text {sw }}$ is linked to atmospheric temperature by a simple polynomial relation. ${ }^{61}$ Starting from a set of initial conditions (steady state), the evolution of the system described in Figure 10.8 obeys a set of coupled differential equations:

$$
\begin{gathered}
\mathrm{d} M_{\mathrm{c}} / \mathrm{dt}=(1-\beta) F_{\mathrm{sw}}-\beta F_{\mathrm{cw}}-F_{\mathrm{cm}}, \\
\mathrm{d} M_{\mathrm{p}} / \mathrm{dt}=\beta\left(F_{\mathrm{sw}}+F_{\mathrm{cw}}\right)-F_{\mathrm{sub}} .
\end{gathered}
$$

For the sake of simplicity, we also impose that the surface reservoir evolves quasistatically (i.e. $F_{\mathrm{sw}}$ responds instantaneously to any change in input flux; e.g. mid-ocean ridge degassing $\left(F_{\mathrm{j}}\right)$, the fraction of subducted carbon degassed in the fore-arc and sub-arc $\left((1-\sigma) F_{\text {sub }}\right)$, or the flux of continental carbon degassing $\left.\left(F_{\mathrm{cm}}\right)\right)$, which gives:

$$
F_{\mathrm{r}}+F_{\mathrm{cm}}+(1-\sigma) F_{\mathrm{sub}}-F_{\mathrm{sw}}=0 .
$$


(a)

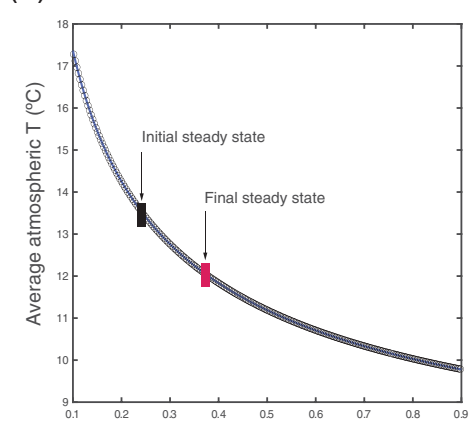

$\beta$ (fraction of pelagic carbonate deposition)

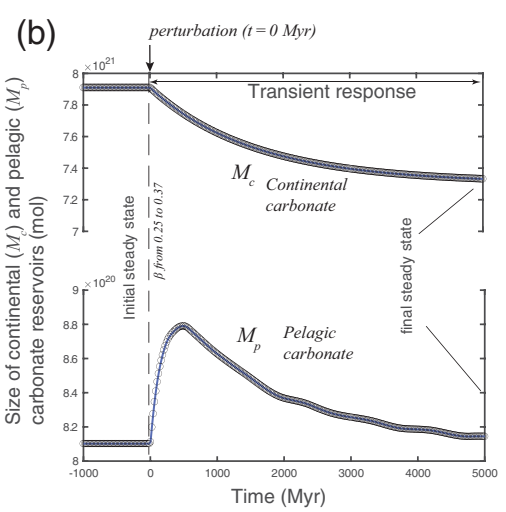

(d)

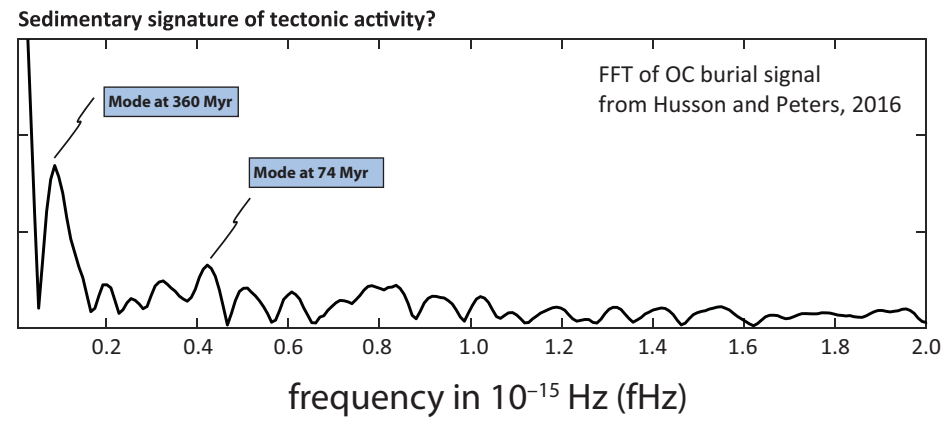

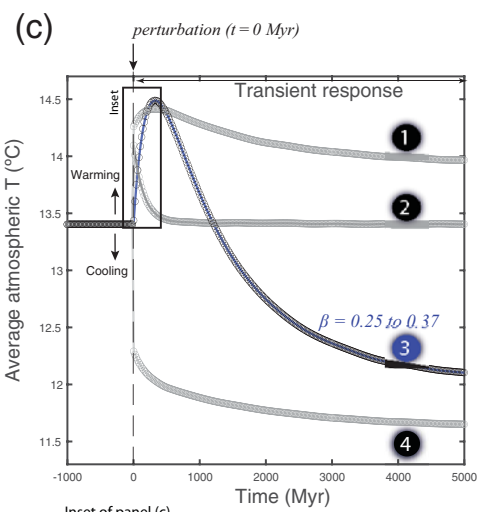

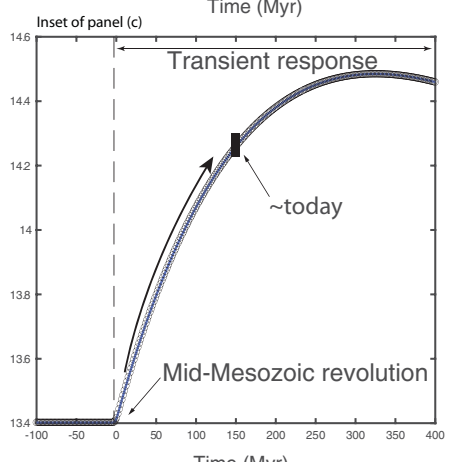

Perturbation models (panel (c))

(1) orogenic $C$ degassing rate $\left(k_{c m}\right):+25 \%$

2 C subduction rate $\left(k_{\text {sub }}\right):+25 \%$

C.

pelagic carbonate deposition ( $\beta$ ): $+75 \%$

e.g. mid-Mesozoic pelagic biominerals

C subduction efficiency ( $\sigma):+25 \%$

e.g. long-term cooling, change in slab hydration/

Figure 10.9 Non-steady-state response of the carbonate cycle to geodynamic and biological forcing: perturbation analysis. (a) Average atmospheric temperature obtained by solving the differential system of equations analytically (cf. Supplementary Online Materials) for values of $\beta$ ranging from 0.1 (continental mode) to 0.9 (pelagic mode). (b) Size of continental $\left(M_{\mathrm{c}}\right)$ and pelagic $\left(M_{\mathrm{p}}\right)$ reservoirs as a function of time after initial perturbation of the steady state (Figure 10.6). At time $0, \beta$ is subjected to a step rise from 0.25 to 0.37 and the system is left to evolve. The transient values of $M_{\mathrm{c}}$ and $M_{\mathrm{p}}$ are tracked for 5 Gyr. (c) (Upper Panel) The shape and response time of the system (average temperature) for perturbations in $\beta$, $\sigma, k_{\mathrm{cm}}$, and $k_{\mathrm{sub}}$ are 
Perturbation analysis reveals a few important patterns (Figure 10.6). First, the shape and relaxation time varies over two orders of magnitudes. It is shorter when perturbation mostly affects the pelagic reservoir where residence time is short (e.g. $\sigma$ ) and it is longer when it affects both pelagic and continental reservoirs (e.g. $\beta, \zeta$ ). Modification of the rate of subduction $\left(k_{\text {sub }}\right)$ may also induce very long relaxation times because it affects the degassing of continental carbonates by arc magmatism (rate $k_{\mathrm{am}}$ ) via $\zeta$ and thus $M_{\mathrm{c}}$. Second, the non-steady-state response to augmentation (e.g. in $\beta$ ) involves an initial stage of atmospheric heating ( $\beta=0.25-0.37$ leads to $\sim 2{ }^{\circ} \mathrm{C}$ warming over the next $500 \mathrm{Myr}$ ), followed much later by relaxation to an atmospheric temperature that is cooler than the initial condition.

The important point is that paleoclimates most likely reflect a non-steady-state dynamic of the carbon cycle. This behavior prevails over timescales that can reach hundreds of millions of years (Figure 10.9). For example, we find that the signal corresponding to the time evolution of continental OC burial from Husson and Peters ${ }^{37}$ contains at least two salient modes at $\sim 0.08$ and $\sim 0.4 \mathrm{fHz}$, equivalent to periods of 360 and $74 \mathrm{Myr}$, respectively (Figure 10.9d), which are typical of tectonic events; the former is most likely linked to supercontinent cycles. Surprisingly, biological evolution may cause long-term non-steadystate responses from the geological carbon cycle, too (Figure 10.9c). In this case, the timescale of the response is not controlled by the biosphere, but by the large residence time of carbon in lithospheric reservoirs, particularly continents.

\subsection{The Way Forward}

We have shown that the subduction zone and its processes regulate three major properties of the geological carbon cycle: its steady-state fluxes - its pace; its episodic changes in pace the pulse; and its stunning persistence over geological time - its longevity. These are the properties of a dynamic system characterized by self-stabilizing feedback between exogenic and endogenic carbon on Earth. This feedback is rooted in four levels of complexity compositional, biological, tectonic, and kinetic - that transcend all scales.

Top-down feedback arises through the heterogeneous composition of subducted rocks. The long-term persistence of oceans, which is so important to the functioning of the subduction-zone carbon cycle, was in part linked to biological evolution and its role in

Figure 10.9 (cont.) compared. It is often the non-steady-state response of the system that matters when studying the long-term climatic (and isotopic ${ }^{152}$ ) impact of geodynamic transitions and/or biological innovations. (Lower Panel) Magnification of the $400 \mathrm{Myr}$ following the perturbation, with the approximate location of the present time with respect to the mid-Mesozoic revolution. ${ }^{6}$ (d) Pulse of the OC cycle on Earth over geological timescales. Fourier transform of the OC burial flux of Ref. 37 showing two dominant main modes. Typical frequencies are in femtohertz. Surprisingly, the signature of the supercontinental cycle at around $0.08 \mathrm{fHz}$ seems to be significant, despite the important noise of the signal. FFT $=$ fast Fourier transform. 
maintaining an elevated, out-of-equilibrium concentration of $\mathrm{O}_{2}$ in the atmosphere. Yet carbon deposition itself does not control when, where, and how subduction occurs; there is a contingency at the heart of the carbon cycle, contributing to its kinetic complexity. The relative slowness of the geological cycle of carbon is important for us, as a society, because it sets the ultimate threshold of carbon fluxes that anthropogenic $\mathrm{CO}_{2}$ emissions may not exceed without long-lasting consequences for the atmosphere, ocean, and biosphere ${ }^{142,143}$; that is, it is a measure of the fragility of the surface geobiosphere.

Subduction zones transform and modify the reactivity of carbon, exerting primary bottom-up feedback control on the pace of the carbon cycle and its associated redox processes over geological timescales. We still do not understand well enough the microscopic processes of the liquid and solid carbon carrier phases of carbon that give rise to the fluxes that we observe. Although slow, the subduction carbon cycle proves surprisingly dynamic and subject to periodic accelerations and decelerations. This rhythmicity, or pulse, is controlled in part by the collision and subduction dynamics of Earth's tectonic building blocks. The dynamism of the southwest Pacific is a natural window onto the pulse of the carbon cycle today and in the past.

Subduction zones are components of a larger planetary system that is dynamic and in constant evolution; this system includes continents, oceans, and the biosphere. Geological hindsight shows that not only the pace, ${ }^{31}$ but also the pulse and longevity of an atmospheric composition may record nonequilibrium planetary processes. This may include life, but also active tectonics. On Earth, the complex frequency distribution of the atmospheric compositional signal testifies to the size of the geochemical reservoirs, the vigor and nature of tectonic processes, and the presence of active biological life. Despite large uncertainties, our survey suggests that the heterogeneous subduction system is - today and possibly since the Mesozoic - in disequilibrium. Pelagic deposition exceeds carbonate subduction, which itself exceeds degassing from fore-arc and magmatic arc systems (Table 10.1).

\subsection{Limits to Knowledge and Unknowns}

There are several remaining questions about the role of subduction in the carbon cycle, including:

- What is the hydration and thermal structure of subducting slabs?

- What was the subduction efficiency before the Mid-Mesozoic revolution?

- What is the mechanical behavior and fate of limestones in the subduction zone?

- When and how will the Atlantic Ring of Fire form?

- Is Earth's carbon cycle unique in the universe?

\section{Acknowledgments}

We thank Tyler Volk and Jerôme Noir for helpful discussions about box modeling the carbonate cycle, Heather Stoll for discussions of Cenozoic evolution, Peter Ulmer and Olivier 
Bachmann for informal reviews, and Mary Edmonds for her comments on an earlier version of the manuscript. Special thanks go to postdocs and graduate students of the "Physical Geobiology Group," the efforts of Xin Zhong to improve the modeling of the carbon cycling, and the insightful comments of Jonathan Viaud Murat, Gabriela Ligeza, and Hichem Ben Lakhdar, who have been precious and constant sources of motivation. Katy Evans reviewed this chapter and provided valuable suggestions for improvements. The authors wish to thank Isabelle Daniel and Beth Orcutt for their tact, patience, and competence in handling the chapter. This project is funded through a Branco Weiss Fellowship (MEG).

\section{Questions for the Classroom}

1. How slow is the slow carbon cycle and why does it matter for our society?

2. How does solar energy influence the subduction carbon cycle?

3. Can transitions in the geological carbon cycle influence biological evolution and how?

4. Why is water so critical for biological metabolisms and for the long-term carbon cycle?

\section{References}

1. Sleep, N. H. Stagnant lid convection and carbonate metasomatism of the deep continental lithosphere. Geochemistry, Geophysics, Geosystems 10, Q11010 (2009).

2. Hayes, J. M. \& Waldbauer, J. R. The carbon cycle and associated redox processes through time. Philosophical Transactions of the Royal Society of London B: Biological Sciences 361, 931-950 (2006).

3. Volk, T. Sensitivity of climate and atmospheric $\mathrm{CO}_{2}$ to deep-ocean and shallowocean carbonate burial. Nature 337, 637-640 (1989).

4. Galvez, M. E. \& Gaillardet, J. Historical constraints on the origins of the carbon cycle concept. Comptes Rendus Geoscience 344, 549-567 (2012).

5. Wallmann, K. Controls on the Cretaceous and Cenozoic evolution of seawater composition, atmospheric $\mathrm{CO}_{2}$ and climate. Geochimica et Cosmochimica Acta $\mathbf{6 5}$, 3005-3025 (2001).

6. Ridgwell, A. A Mid Mesozoic Revolution in the regulation of ocean chemistry. Marine Geology 217, 339-357 (2005).

7. Cartapanis, O., Galbraith, E. D., Bianchi, D. \& Jaccard, S. Carbon burial in deep-sea sediment and implications for oceanic inventories of carbon and alkalinity over the last glacial cycle. Climate of the Past 14, 1819-1850 (2018).

8. Caldeira, K. Continental-pelagic carbonate partitioning and the global carbonatesilicate cycle. Geology 19, 204-206 (1991).

9. Wilkinson, B. H. \& Walker, J. C. Phanerozoic cycling of sedimentary carbonate. American Journal of Science 289, 525-548 (1989).

10. Clift, P. \& Vannucchi, P. Controls on tectonic accretion versus erosion in subduction zones: implications for the origin and recycling of the continental crust. Reviews of Geophysics 42, 2003RG000127 (2004). 
11. Mottl, M. J., McCollom, T. M., Wheat, C. G. \& Fryer, P. Decarbonation of the subducting Pacific plate triggered by the lawsonite-to-epidote transition beneath the Mariana forearc serpentinite mud volcanoes. In: American Geological Union Fall Meeting Abstracts, U51C-03 (2008).

12. Allard, P. et al. Prodigious emission rates and magma degassing budget of major, trace and radioactive volatile species from Ambrym basaltic volcano, Vanuatu Island arc. Journal of Volcanology and Geothermal Research 322, 119-143 (2016).

13. Sakai, H. et al. Venting of carbon dioxide-rich fluid and hydrate formation in midOkinawa trough backarc basin. Science 248, 1093-1096 (1990).

14. Sleep, N. H. \& Zahnle, K. Carbon dioxide cycling and implications for climate on ancient Earth. Journal of Geophysical Research: Planets (1991-2012) 106, 1373-1399 (2001).

15. Lee, C.-T. A. et al. Continental arc-island arc fluctuations, growth of crustal carbonates, and long-term climate change. Geosphere 9, 21-36 (2013).

16. Mason, E., Edmonds, M. \& Turchyn, A. V. Remobilization of crustal carbon may dominate volcanic arc emissions. Science 357, 290 (2017).

17. Foley, S. F. \& Fischer, T. P. An essential role for continental rifts and lithosphere in the deep carbon cycle. Nature Geoscience 10, 897 (2017).

18. McKenzie, N. R. et al. Continental arc volcanism as the principal driver of icehousegreenhouse variability. Science 352, 444-447 (2016).

19. Krissansen-Totton, J., Buick, R. \& Catling, D. C. A statistical analysis of the carbon isotope record from the Archean to Phanerozoic and implications for the rise of oxygen. American Journal of Science 315, 275-316 (2015).

20. Campbell, I. \& Taylor, S. No water, no granites - no oceans, no continents. Geophysical Research Letters 10, 1061-1064 (1983).

21. Kelemen, P. B. \& Manning, C. E. Reevaluating carbon fluxes in subduction zones, what goes down, mostly comes up. Proceedings of the National Academy of Sciences 112, E3997-E4006 (2015).

22. Caldeira, K. Enhanced Cenozoic chemical weathering and the subduction of pelagic carbonate. Nature 357, 578-581 (1992).

23. Archer, D. E. An atlas of the distribution of calcium carbonate in sediments of the deep sea. Global Biogeochemical Cycles 10, 159-174 (1996).

24. Zachos, J. C. et al. Rapid acidification of the ocean during the Paleocene-Eocene thermal maximum. Science, 308, 1611-1615 (2005).

25. Plank, T. \& Langmuir, C. H. The chemical composition of subducting sediment and its consequences for the crust and mantle. Chemical Geology 145, 325-394 (1998).

26. Clift, P. D. A revised budget for Cenozoic sedimentary carbon subduction. Reviews of Geophysics 55, 97-125 (2017).

27. Johnston, F. K., Turchyn, A. V. \& Edmonds, M. Decarbonation efficiency in subduction zones: implications for warm Cretaceous climates. Earth and Planetary Science Letters 303, 143-152 (2011).

28. Arndt, S. et al. Quantifying the degradation of organic matter in marine sediments: a review and synthesis. Earth-Science Reviews 123, 53-86 (2013).

29. Cartapanis, O., Bianchi, D., Jaccard, S. L. \& Galbraith, E. D. Global pulses of organic carbon burial in deep-sea sediments during glacial maxima. Nature Coтmиnications 7, 10796 (2016).

30. del Giorgio, P. A. \& Duarte, C. M. Respiration in the open ocean. Nature 420, 379-384 (2002). 
31. Krissansen-Totton, J., Bergsman, D. S. \& Catling, D. C. On detecting biospheres from chemical thermodynamic disequilibrium in planetary atmospheres. Astrobiology 16, 39-67 (2016).

32. Cui, X., Bianchi, T. S., Jaeger, J. M. \& Smith, R. W. Biospheric and petrogenic organic carbon flux along southeast Alaska. Earth and Planetary Science Letters 452, 238-246 (2016).

33. Galy, V., Peucker-Ehrenbrink, B. \& Eglinton, T. Global carbon export from the terrestrial biosphere controlled by erosion. Nature 521, 204 (2015).

34. Blair, N. E. \& Aller, R. C. The fate of terrestrial organic carbon in the marine environment. Annual Review of Marine Science 4, 401-423 (2012).

35. Hilton, R. G. et al. Tropical-cyclone-driven erosion of the terrestrial biosphere from mountains. Nature Geoscience 1, 759-762 (2008).

36. Hilton, R. G. et al. Erosion of organic carbon in the Arctic as a geological carbon dioxide sink. Nature 524, 84-87 (2015).

37. Husson, J. M. \& Peters, S. E. Atmospheric oxygenation driven by unsteady growth of the continental sedimentary reservoir. Earth and Planetary Science Letters $\mathbf{4 6 0}$, 68-75 (2017).

38. Bao, R. et al. Tectonically-triggered sediment and carbon export to the Hadal zone. Nature Communications 9, 121 (2018).

39. Beyssac, O., Rouzaud, J.-N., Goffé, B., Brunet, F. \& Chopin, C. Graphitization in a high-pressure, low-temperature metamorphic gradient: a Raman microspectroscopy and HRTEM study. Contributions to Mineralogy and Petrology 143, 19-31 (2002).

40. Galvez, M. E. et al. Graphite formation by carbonate reduction during subduction. Nature Geoscience 6, 473-477 (2013).

41. Adam, P., Schneckenburger, P., Schaeffer, P. \& Albrecht, P. Clues to early diagenetic sulfurization processes from mild chemical cleavage of labile sulfur-rich geomacromolecules. Geochimica et Cosmochimica Acta 64, 3485-3503 (2000).

42. Helgeson, H. C., Richard, L., McKenzie, W. F., Norton, D. L. \& Schmitt, A. A chemical and thermodynamic model of oil generation in hydrocarbon source rocks. Geochimica et Cosmochimica Acta 73, 594-695 (2009).

43. Berner, R. A. Burial of organic carbon and pyrite sulfur in the modern ocean: its geochemical and environmental significance. American Journal of Science 282, 451-473 (1982).

44. Petrenko, V. V. et al. Minimal geological methane emissions during the Younger Dryas-Preboreal abrupt warming event. Nature 548, 443-446 (2017).

45. Oohashi, K., Hirose, T. \& Shimamoto, T. Shear-induced graphitization of carbonaceous materials during seismic fault motion: experiments and possible implications for fault mechanics. Journal of Structural Geology 33, 1122-1134 (2011).

46. Berthonneau, J. et al. Mesoscale structure, mechanics, and transport properties of source rocks' organic pore networks. Proceedings of the National Academy of Sciences 115, 12365 (2018).

47. Weck, P. F. et al. Model representations of kerogen structures: an insight from density functional theory calculations and spectroscopic measurements. Scientific Reports 7, 7068 (2017).

48. Connolly, J. A. D. \& Galvez, M. E. Electrolytic fluid speciation by Gibbs energy minimization and implications for subduction zone mass transfer. Earth and Planetary Science Letters 501, 90-102 (2018). 
49. Zhang, S., Ague, J. J. \& Brovarone, A. V. Degassing of organic carbon during regional metamorphism of pelites, Wepawaug Schist, Connecticut, USA. Chemical Geology 490, 30-44 (2018).

50. Alt, J. C. et al. Recycling of water, carbon, and sulfur during subduction of serpentinites: a stable isotope study of Cerro del Almirez, Spain. Earth and Planetary Science Letters 327-328, 50-60 (2012).

51. Alt, J. C. et al. The role of serpentinites in cycling of carbon and sulfur: seafloor serpentinization and subduction metamorphism. Lithos 178, 40-54 (2013).

52. Nakamura, K. \& Kato, Y. Carbonatization of oceanic crust by the seafloor hydrothermal activity and its significance as a $\mathrm{CO}_{2}$ sink in the Early Archean. Geochimica et Cosmochimica Acta 68, 4595-4618 (2004).

53. Shibuya, T., Komiya, T., Nakamura, K., Takai, K. \& Maruyama, S. Highly alkaline, high-temperature hydrothermal fluids in the early Archean ocean. Precambrian Research 182, 230-238 (2010).

54. Ueda, H., Sawaki, Y. \& Maruyama, S. Reactions between olivine and $\mathrm{CO}_{2}$-rich seawater at $300^{\circ} \mathrm{C}$ : implications for $\mathrm{H}_{2}$ generation and $\mathrm{CO}_{2}$ sequestration on the early Earth. Geoscience Frontiers 8, 387-396 (2017).

55. Dhuime, B., Hawkesworth, C. J., Cawood, P. A. \& Storey, C. D. A change in the geodynamics of continental growth 3 billion years ago. Science 335, 1334-1336 (2012).

56. Sieber, M. J., Hermann, J. \& Yaxley, G. M. An experimental investigation of C-O-H fluid-driven carbonation of serpentinites under forearc conditions. Earth and Planetary Science Letters 496, 178-188 (2018).

57. Aiuppa, A., Fischer, T. P., Plank, T., Robidoux, P. \& Di Napoli, R. Along-arc, interarc and arc-to-arc variations in volcanic gas $\mathrm{CO}_{2} / \mathrm{ST}$ ratios reveal dual source of carbon in arc volcanism. Earth-Science Reviews 168, 24-47 (2017).

58. Chiodini, G. et al. First ${ }^{13} \mathrm{C} /{ }^{12} \mathrm{C}$ isotopic characterisation of volcanic plume $\mathrm{CO}_{2}$. Bulletin of Volcanology 73, 531-542 (2011).

59. Stolper, E. \& Newman, S. The role of water in the petrogenesis of Mariana trough magmas. Earth and Planetary Science Letters 121, 293-325 (1994).

60. Bjørnerud, M. G. \& Austrheim, H. Inhibited eclogite formation: the key to the rapid growth of strong and buoyant Archean continental crust. Geology 32, 765-768 (2004).

61. Berner, R. A., Lasaga, A. C. \& Garrels, R. M. The carbonate-silicate geochemical cycle and its effect on atmospheric carbon dioxide over the past 100 million years. American Journal of Science 283, 641-683 (1983).

62. Goldschmidt, V. M. Die Gesetze der Gesteinsmetamorphose, mit beispielen aus der Geologie des sudlichen Norwegens. Videnskapsselskapets Skrifter, Mathematikernaturvissenshaft, KL, 1-16 (1912).

63. Berner, R. A. The long-term carbon cycle, fossil fuels and the atmospheric $\mathrm{CO}_{2}$. Nature 426, 323-326 (2003).

64. McGary, R. S., Evans, R. L., Wannamaker, P. E., Elsenbeck, J. \& Rondenay, S. Pathway from subducting slab to surface for melt and fluids beneath Mount Rainier. Nature 511, 338 (2014).

65. Poli, S., Franzolin, E., Fumagalli, P. \& Crottini, A. The transport of carbon and hydrogen in subducted oceanic crust: an experimental study to $5 \mathrm{GPa}$. Earth and Planetary Science Letters 278, 350-360 (2009).

66. Ulmer, P. \& Trommsdorff, V. Serpentine stability to mantle depths and subductionrelated magmatism. Science 268, 858-861 (1995). 
67. Galvez, M. E., Connolly, J. A. D. \& Manning, C. E. Implications for metal and volatile cycles from the $\mathrm{pH}$ of subduction zone fluids. Nature 539, 420-424 (2016).

68. Tsujimori, T. \& Ernst, W. Lawsonite blueschists and lawsonite eclogites as proxies for palaeo-subduction zone processes: a review. Journal of Metamorphic Geology 32, 437-454 (2014).

69. Ague, J. J. Release of $\mathrm{CO}_{2}$ from carbonate rocks during regional metamorphism of lithologically heterogeneous crust. Geology 28, 1123-1126 (2000).

70. Ague, J. J. \& Nicolescu, S. Carbon dioxide released from subduction zones by fluidmediated reactions. Nature Geoscience 7, 355-360 (2014).

71. Galvez, M. E. et al. Metasomatism and graphite formation at a lithological interface in Malaspina (Alpine Corsica, France). Contributions to Mineralogy and Petrology 166, 1687-1708 (2013).

72. Pimm, A. C. Sedimentology and history of the northeastern Indian Ocean from Late Cretaceous to Recent. Initial Reports of the Deep Sea Drilling Project 22, 717-804 (1974).

73. Gerya, T. V. \& Yuen, D. A. Rayleigh-Taylor instabilities from hydration and melting propel 'cold plumes' at subduction zones. Earth and Planetary Science Letters 212, 47-62 (2003).

74. Skora, S. et al. Hydrous phase relations and trace element partitioning behaviour in calcareous sediments at subduction-zone conditions. Journal of Petrology 56, 953-980 (2015).

75. Kang, N., Schmidt, M. W., Poli, S., Franzolin, E. \& Connolly, J. A. Melting of siderite to $20 \mathrm{GPa}$ and thermodynamic properties of $\mathrm{FeCO}_{3}$-melt. Chemical Geology 400, 34-43 (2015).

76. Foustoukos, D. I. \& Mysen, B. O. The structure of water-saturated carbonate melts. American Mineralogist 100, 35-46 (2015).

77. Russell, J. K., Porritt, L. A., Lavallée, Y. \& Dingwell, D. B. Kimberlite ascent by assimilation-fuelled buoyancy. Nature 481, 352 (2012).

78. Baxter, E. F. \& Caddick, M. J. Garnet growth as a proxy for progressive subduction zone dehydration. Geology 41, 643-646 (2013).

79. Frezzotti, M. L., Selverstone, J., Sharp, Z. D. \& Compagnoni, R. Carbonate dissolution during subduction revealed by diamond-bearing rocks from the Alps. Nature Geoscience 4, 703-706 (2011).

80. Galvez, M. E., Manning, C. E., Connolly, J. A. \& Rumble, D. The solubility of rocks in metamorphic fluids: a model for rock-dominated conditions to upper mantle pressure and temperature. Earth and Planetary Science Letters 430, 486-498 (2015).

81. Gorman, P. J., Kerrick, D. M. \& Connolly, J. A. D. Modeling open system metamorphic decarbonation of subducting slabs. Geochemistry, Geophysics, Geosystems 7, Q04007 (2006).

82. Connolly, J. A. D. Computation of phase equilibria by linear programming: a tool for geodynamic modeling and its application to subduction zone decarbonation. Earth and Planetary Science Letters 236, 524-541 (2005).

83. Hirschmann, M. M. Comparative deep Earth volatile cycles: the case for $\mathrm{C}$ recycling from exosphere/mantle fractionation of major $\left(\mathrm{H}_{2} \mathrm{O}, \mathrm{C}, \mathrm{N}\right)$ volatiles and from $\mathrm{H}_{2} \mathrm{O}$ / $\mathrm{Ce}, \mathrm{CO}_{2} / \mathrm{Ba}$, and $\mathrm{CO}_{2} / \mathrm{Nb}$ exosphere ratios. Earth and Planetary Science Letters $\mathbf{5 0 2}$, 262-273 (2018).

84. Thomson, A. R., Walter, M. J., Kohn, S. C. \& Brooker, R. A. Slab melting as a barrier to deep carbon subduction. Nature 529, 76-79 (2016). 
85. Wyllie, P. J. \& Tuttle, O. F. The System $\mathrm{CaO}-\mathrm{CO}_{2}-\mathrm{H}_{2} \mathrm{O}$ and the origin of carbonatites. Journal of Petrology 1, 1-46 (1960).

86. Poli, S. Carbon mobilized at shallow depths in subduction zones by carbonatitic liquids. Nature Geoscience 8, 633-636 (2015).

87. Kang, N. \& Schmidt, M. W. The melting of subducted banded iron formations. Earth and Planetary Science Letters 476, 165-178 (2017).

88. Syracuse, E. M., van Keken, P. E. \& Abers, G. A. The global range of subduction zone thermal models. Physics of the Earth and Planetary Interiors 183, 73-90 (2010).

89. Penniston-Dorland, S. C., Kohn, M. J. \& Manning, C. E. The global range of subduction zone thermal structures from exhumed blueschists and eclogites: rocks are hotter than models. Earth and Planetary Science Letters 428, 243-254 (2015).

90. Angiboust, S., Pettke, T., De Hoog, J. C., Caron, B. \& Oncken, O. Channelized fluid flow and eclogite-facies metasomatism along the subduction shear zone. Journal of Petrology 55, 883-916 (2014).

91. Worzewski, T., Jegen, M., Kopp, H., Brasse, H. \& Castillo, W. T. Magnetotelluric image of the fluid cycle in the Costa Rican subduction zone. Nature Geoscience 4, 108 (2011).

92. Piccoli, F., Brovarone, A. V., Beyssac, O., Martinez, I., Ague, J. J. \& Chaduteau, C. Carbonation by fluid-rock interactions at high-pressure conditions: implications for carbon cycling in subduction zones. Earth and Planetary Science Letters 445, 146-159 (2016).

93. Tumiati, S., Godard, G., Martin, S., Malaspina, N. \& Poli, S. Ultra-oxidized rocks in subduction mélanges? Decoupling between oxygen fugacity and oxygen availability in a Mn-rich metasomatic environment. Lithos 226, 116-130 (2015).

94. Connolly, J. A. D. \& Cesare, B. C-O-H-S fluid composition and oxygen fugacity in graphitic metapelites. Journal of Metamorphic Geology 11, 379-388 (1993).

95. Brovarone, A. V. et al. Massive production of abiotic methane during subduction evidenced in metamorphosed ophicarbonates from the Italian Alps. Nature Coтmиnications 8, 14134 (2017).

96. Weis, P. L., Friedman, I. \& Gleason, J. P. The origin of epigenetic graphite: evidence from isotopes. Geochimica et Cosmochimica Acta 45, 2325-2332 (1981).

97. Rumble III, D., Duke, E. F. \& Hoering, T. L. Hydrothermal graphite in New Hampshire: evidence of carbon mobility during regional metamorphism. Geology 14, 452-455 (1986).

98. Malvoisin, B., Chopin, C., Brunet, F. \& Galvez, M. E. Low-temperature wollastonite formed by carbonate reduction: a marker of serpentinite redox conditions. Journal of Petrology 53, 159-176 (2012).

99. Rohrbach, A. \& Schmidt, M. W. Redox freezing and melting in the Earth's deep mantle resulting from carbon-iron redox coupling. Nature 472, 209-212 (2011).

100. Dalton, J. A. \& Wood, B. J. The compositions of primary carbonate melts and their evolution through wallrock reaction in the mantle. Earth and Planetary Science Letters 119, 511-525 (1993).

101. Jones, A. P., Genge, M. \& Carmody, L. Carbonate melts and carbonatites. Reviews in Mineralogy and Geochemistry 75, 289-322 (2013).

102. Stolper, E., Fine, G., Johnson, T. \& Newman, S. Solubility of carbon dioxide in albitic melt. American Mineralogist 72, 1071-1085 (1987). 
103. Mysen, B. Experimental, in-situ carbon solution mechanisms and isotope fractionation in and between $(\mathrm{C}-\mathrm{O}-\mathrm{H})$-saturated silicate melt and silicate-saturated $(\mathrm{C}-\mathrm{O}-\mathrm{H})$ fluid to upper mantle temperatures and pressures. Earth and Planetary Science Letters 459, 352-361 (2017).

104. Pirard, C. \& Hermann, J. Experimentally determined stability of alkali amphibole in metasomatised dunite at sub-arc pressures. Contributions to Mineralogy and Petrology 169, 1-26 (2014).

105. Korsakov, A. V. \& Hermann, J. Silicate and carbonate melt inclusions associated with diamonds in deeply subducted carbonate rocks. Earth and Planetary Science Letters 241, 104-118 (2006).

106. Zhang, C., Yu, X.-Y. \& Jiang, T.-L. Mineral association and graphite inclusions in nephrite jade from Liaoning, northeast China: implications for metamorphic conditions and ore genesis. Geoscience Frontiers 10, 425-437 (2019).

107. Rothman, D. H., Hayes, J. M. \& Summons, R. E. Dynamics of the Neoproterozoic carbon cycle. Proceedings of the National Academy of Sciences 100, 8124-8129 (2003).

108. Cooper, P. A. \& Taylor, B. Polarity reversal in the Solomon Islands arc. Nature 314, 428 (1985).

109. Hoareau, G. et al. Did high Neo-Tethys subduction rates contribute to early Cenozoic warming? Climate of the Past 11, 1751-1767 (2015).

110. Pubellier, M. \& Meresse, F. Phanerozoic growth of Asia: geodynamic processes and evolution. Journal of Asian Earth Sciences 72, 118-128 (2013).

111. Condie, K. C. \& O'Neill, C. The Archean-Proterozoic boundary: 500 My of tectonic transition in Earth history. American Journal of Science 310, 775-790 (2010).

112. Selverstone, J. \& Gutzler, D. S. Post-125 Ma carbon storage associated with continent-continent collision. Geology 21, 885-888 (1993).

113. Tapponnier, P. et al. Oblique stepwise rise and growth of the Tibet Plateau. Science 294, 1671-1677 (2001).

114. Gaillardet, J. \& Galy, A. Himalaya - carbon sink or source? Science 320, 1727-1728 (2008).

115. Raymo, M. E., Ruddiman, W. F. \& Froelich, P. N. Influence of late Cenozoic mountain building on ocean geochemical cycles. Geology 16, 649-653 (1988).

116. Hilton, R. G., Galy, A. \& Hovius, N. Riverine particulate organic carbon from an active mountain belt: importance of landslides. Global Biogeochemical Cycles 22, GB1017 (2008).

117. Hilton, R. G., Gaillardet, J., Calmels, D. \& Birck, J.-L. Geological respiration of a mountain belt revealed by the trace element rhenium. Earth and Planetary Science Letters 403, 27-36 (2014).

118. Torres, M. A., West, A. J. \& Li, G. Sulphide oxidation and carbonate dissolution as a source of $\mathrm{CO}_{2}$ over geological timescales. Nature 507, 346-349 (2014).

119. Tomkins, A. G., Rebryna, K. C., Weinberg, R. F. \& Schaefer, B. F. Magmatic sulfide formation by reduction of oxidized arc basalt. Journal of Petrology 53, 1537-1567 (2012).

120. Sternai, P. et al. On the influence of the asthenospheric flow on the tectonics and topography at a collision-subduction transition zones: comparison with the eastern Tibetan margin. Journal of Geodynamics 100, 184-197 (2016).

121. Royden, L. H., Burchfiel, B. C. \& van der Hilst, R. D. The geological evolution of the Tibetan Plateau. Science 321, 1054-1058 (2008). 
122. Edmond, J. M. \& Huh, Y. Non-steady state carbonate recycling and implications for the evolution of atmospheric $\mathrm{PCO}_{2}$. Earth and Planetary Science Letters 216, 125-139 (2003).

123. Soo, R. M., Hemp, J., Parks, D. H., Fischer, W. W. \& Hugenholtz, P. On the origins of oxygenic photosynthesis and aerobic respiration in Cyanobacteria. Science 355, 1436-1440 (2017).

124. Bidle, K. D. \& Falkowski, P. G. Cell death in planktonic, photosynthetic microorganisms. Nature Reviews Microbiology 2, 643-655 (2004).

125. Fuhrman, J. A. Marine viruses and their biogeochemical and ecological effects. Nature 399, 541-548 (1999).

126. Forterre, P. \& Prangishvili, D. The great billion-year war between ribosome-and capsid-encoding organisms (cells and viruses) as the major source of evolutionary novelties. Annals of the New York Academy of Sciences 1178, 65-77 (2009).

127. Duncan, M. S. \& Dasgupta, R. Rise of Earth's atmospheric oxygen controlled by efficient subduction of organic carbon. Nature Geoscience 10, 387-392 (2017).

128. Godderis, Y. \& Veizer, J. Tectonic control of chemical and isotopic composition of ancient oceans; the impact of continental growth. American Journal of Science 300, 434-461 (2000).

129. Knoll, A. H. Biomineralization and evolutionary history. Reviews in Mineralogy and Geochemistry 54, 329-356 (2003).

130. Fischer, W., Hemp, J. \& Johnson, J. E. Evolution of oxygenic photosynthesis. Annual Review of Earth and Planetary Sciences 44, 647-683 (2016).

131. Falkowski, P. G. \& Godfrey, L. V. Electrons, life and the evolution of Earth's oxygen cycle. Philosophical Transactions of the Royal Society B: Biological Sciences 363, 2705-2716 (2008).

132. Halevy, I. \& Bachan, A. The geologic history of seawater pH. Science 355, 1069 (2017).

133. Anbar, A. D. Elements and evolution. Science 322, 1481-1483 (2008).

134. Catling, D. C., Zahnle, K. J. \& McKay, C. Biogenic methane, hydrogen escape, and the irreversible oxidation of early Earth. Science 293, 839-843 (2001).

135. Driscoll, P. \& Bercovici, D. Divergent evolution of Earth and Venus: influence of degassing, tectonics, and magnetic fields. Icarus 226, 1447-1464 (2013).

136. Schwartzman, D. W. \& Volk, T. Biotic enhancement of weathering and the habitability of Earth. Nature 340, 457 (1989).

137. Hemingway, J. D. et al. Microbial oxidation of lithospheric organic carbon in rapidly eroding tropical mountain soils. Science 360, 209-212 (2018).

138. Peters, S. E. \& Gaines, R. R. Formation of the Great Unconformity as a trigger for the Cambrian explosion. Nature 484, 363-366 (2012).

139. Berner, R. A. Inclusion of the weathering of volcanic rocks in the geocarbsulf model. American Journal of Science 306, 295-302 (2006).

140. Monteiro, F. M. et al. Why marine phytoplankton calcify. Science Advances 2 , e1501822 (2016).

141. Falkowski, P. G., Fenchel, T. \& Delong, E. F. The microbial engines that drive Earth's biogeochemical cycles. Science 320, 1034-1039 (2008).

142. DePaolo, D. J. Sustainable carbon emissions: the geologic perspective. MRS Energy \& Sustainability - A Review Journal 2, 1-16 (2015).

143. Gruber, N. Warming up, turning sour, losing breath: ocean biogeochemistry under global change. Philosophical Transactions of the Royal Society of London A: Mathematical, Physical and Engineering Sciences 369, 1980-1996 (2011). 
144. Canfield, D., Glazer, A. \& Falkowski, P. The evolution and future of Earth's nitrogen cycle. Science 333, 192-196 (2010).

145. Smith, R. W., Bianchi, T. S., Allison, M., Savage, C. \& Galy, V. High rates of organic carbon burial in fjord sediments globally. Nature Geoscience 8, 450-453 (2015).

146. Burdige, D. J. Preservation of organic matter in marine sediments: controls, mechanisms, and an imbalance in sediment organic carbon budgets? Chemical Reviews 107, 467-485 (2007).

147. Jolivet, L. et al. Mantle flow and deforming continents: from India-Asia convergence to Pacific subduction. Tectonics 37, 2887-2914 (2018).

148. Farquhar, J., Bao, H. \& Thiemens, M. Atmospheric influence of Earth's earliest sulfur cycle. Science 289, 756-758 (2000).

149. Cole, D. B. et al. A shale-hosted Cr isotope record of low atmospheric oxygen during the Proterozoic. Geology 44, 555-558 (2016).

150. Canfield, D. E. et al. Highly fractionated chromium isotopes in Mesoproterozoicaged shales and atmospheric oxygen. Nature Communications 9, 2871 (2018).

151. Reinhard, C. T., Olson, S. L., Schwieterman, E. W. \& Lyons, T. W. False negatives for remote life detection on ocean-bearing planets: lessons from the early Earth. Astrobiology 17, 287-297 (2017).

152. Caves, J. K., Jost, A. B., Lau, K. V. \& Maher, K. Cenozoic carbon cycle imbalances and a variable weathering feedback. Earth and Planetary Science Letters 450, 152-163 (2016). 


\section{Appendix to Chapter 10 \\ How Do Subduction Zones Regulate the Carbon Cycle?}

\section{Supplementary Material: Description of the Model}

What follows is a description of the model presented in Figure 10.7 (main text).

The main features of the model have been presented in the main text (Figure 10.7). It is simplistic in the sense that it neglects organic carbon and sulfur cycles that also operate as transient sources and sinks of $\mathrm{CO}_{2}$ over geological timescales. ${ }^{1,2}$ That said, the mass of the pelagic $\left(M_{\mathrm{p}}\right)$ and continental $\left(M_{\mathrm{c}}\right)$ carbonate reservoirs evolve by exchange of $\mathrm{C}$ (i.e. fluxes $\left.F_{\mathrm{i}}\right)$ with the atmosphere and mantle. We distinguish mid-ocean ridge carbon degassing $\left(F_{\mathrm{j}}\right)$; carbonate subduction $\left(F_{\text {sub }}\right)$, where $\sigma F_{\text {sub }}$ returns to mantle and $(1-\sigma) F_{\text {sub }}$ returns to exosphere; silicate weathering $\left(F_{\mathrm{sw}}\right)$, where $\beta F_{\mathrm{sw}}$ precipitates in the pelagic environment and $(1-\beta) F_{\mathrm{sw}}$ is accreted to continents; carbonate weathering $\left(F_{\mathrm{cw}}\right)$; and continental carbon degassing $\left(F_{\mathrm{cm}}\right)$, where $\zeta F_{\mathrm{cm}}$ is attributed to continental arc degassing and $(1-\zeta)$ $F_{\mathrm{cm}}$ is attributed to orogenic degassing. The initial steady state is obtained with starting conditions chosen and updated from Volk, ${ }^{3}$ to be consistent with present-day values in $\mathrm{C}$ flux and reservoir sizes.

Silicate and continental weathering: The silicate weathering flux $\left(F_{\mathrm{sw}}\right)$ and the continental carbonate weathering flux $\left(F_{\mathrm{cw}}\right)$ are derived from present-day values $\left(F_{\mathrm{sw}, \mathrm{ref}}\right.$ and $\left.F_{\mathrm{cw}, \mathrm{ref}}\right)$ using a weathering rate constant, $f_{\mathrm{wr}} . F_{\mathrm{sw}, \text { ref }}$ is set at $10 \mathrm{Tmol} / \mathrm{yr}$ and $F_{\mathrm{cw}, \mathrm{ref}}$ at $15 \mathrm{Tmol} / \mathrm{yr}$ after Caves et al. ${ }^{2} M_{\mathrm{c}}$ affects the carbonate weathering flux as it departs from the present-day size of the continental reservoir, $M_{\mathrm{c}, \text { ref }}$, estimated at $7583 \times 10^{18} \mathrm{~mol}$. The equations are:

$$
\begin{gathered}
F_{\mathrm{sw}}=F_{\mathrm{sw}, \mathrm{ref}} f_{\mathrm{wr}}, \\
F_{\mathrm{cw}}=F_{\mathrm{cw}, \text { ref }} f_{\mathrm{wr}} M_{\mathrm{c}} / M_{\mathrm{c}, \text { ref }} .
\end{gathered}
$$

Link between silicate weathering and atmospheric temperature: The silicate weathering rate constant is linked to atmospheric temperature by a simple polynomial relation from Berner et al. ${ }^{4}$ :

$$
f_{\mathrm{wr}}=1+8.7 \times 10^{-2}\left(T-T_{\text {ref }}\right)+1.9 \times 10^{-3}\left(T-T_{\text {ref }}\right)^{2},
$$

with $T_{\text {ref }}=15^{\circ} \mathrm{C}$. 
Continental carbonate degassing: Orogenic release of $\mathrm{CO}_{2}$ by accreted carbonates is assumed to be proportional to $M_{\mathrm{c}}$ :

$$
F_{\mathrm{cm}}=k_{\mathrm{cm}} M_{\mathrm{c}} .
$$

We attribute $\zeta F_{\mathrm{cm}}$ to continental arc degassing:

$$
\zeta F_{\mathrm{cm}}=k_{\mathrm{am}} M_{\mathrm{c}},
$$

and $(1-\zeta) F_{\mathrm{cm}}$ to orogenic degassing:

$$
(1-\zeta) F_{\mathrm{cm}}=k_{\mathrm{om}} M_{\mathrm{c}}
$$

Therefore, $\zeta$ is an auto-amplification factor that connects continental $\mathrm{C}$ degassing to subduction-zone processes and rates.

Injecting (4) into (6) gives:

$$
\zeta=1-\frac{k_{\mathrm{om}}}{k_{\mathrm{cm}}}
$$

We take $k_{\mathrm{cm}}=3.57 \times 10^{-4} / \mathrm{Myr}$, which we calibrated to reproduce modern-day flux $F_{\mathrm{cm}}$ from Volk. ${ }^{3}$ The parameter $\zeta$ is free to vary and depends on the proportion of continental and island arcs. ${ }^{5}$ For simplicity, the examples depicted in Figure 10.8 consider $\zeta=0$ (island arcs only).

Carbon subduction: The flux of pelagic carbonates entering the subduction zone is also assumed to be proportional to $M_{\mathrm{p}}$ :

$$
F_{\text {sub }}=k_{\text {sub }} M_{\mathrm{p}} .
$$

We take $k_{\text {sub }}=0.0072 \mathrm{Myr}^{-1}$ to approach a present-day carbon subduction flux of $70 \mathrm{MtC} / \mathrm{yr}$. The parameter $\sigma$ is the fraction of subducted carbon the subducts to beyond sub-arc depths, and it is taken at 0.6 (cf. main text). The present-day size of the continental reservoir, $M_{\mathrm{p}, \mathrm{ref}}$, is $0.917 \times 10^{21} \mathrm{~mol}^{6}{ }^{6} \mathrm{We}$ note that this value is about 10 times larger than the value adopted by Volk. ${ }^{3}$ While this modifies the response time of the whole system compared to that expected from Volk, ${ }^{3}$ it does not change its internal structure (i.e. its fundamental dynamics).

Biological factors: The parameter $\beta$ is the partitioning of carbonate between pelagic and continental (accretion) environments. It is set at 0.25 for the initial conditions prior to perturbations.

Mid-ocean ridge and other mantle degassing fluxes: The mid-ocean ridge flux is taken to be $F_{\mathrm{j}}=3 \mathrm{Tmol} / \mathrm{yr}^{6}$

The whole system (Figure 10.7) evolves dynamically from its initial conditions, but the atmospheric subsystem is assumed to evolve quasi-statically during this process (i.e. its response times to changes in input fluxes are infinitely faster than the characteristic timescales of the whole system). The system is solved analytically to find its steady state, which is close to the present-day condition: $M_{\mathrm{c}}=7.909 \times 10^{21}$ mol (i.e. residence time 
$\tau_{\mathrm{c}} \approx 2800 \mathrm{Myr}$ ) $M_{\mathrm{p}}=0.810 \times 10^{21} \mathrm{~mol}$ (i.e. residence time $\tau_{\mathrm{p}} \approx 140 \mathrm{Myr}$ ). This steady state is then used for perturbation analysis (Figure 10.7).

\section{References}

1. Torres, M. A., West, A. J. \& Li, G. Sulphide oxidation and carbonate dissolution as a source of $\mathrm{CO}_{2}$ over geological timescales. Nature 507, 346-349 (2014).

2. Caves, J. K., Jost, A. B., Lau, K. V. \& Maher, K. Cenozoic carbon cycle imbalances and a variable weathering feedback. Earth and Planetary Science Letters 450, 152-163 (2016).

3. Volk, T. Sensitivity of climate and atmospheric $\mathrm{CO}_{2}$ to deep-ocean and shallow-ocean carbonate burial. Nature 337, 637-640 (1989).

4. Berner, R. A., Lasaga, A. C. \& Garrels, R. M. The carbonate-silicate geochemical cycle and its effect on atmospheric carbon dioxide over the past 100 million years. American Journal of Science 283, 641-683 (1983).

5. Lee, C.-T. A. et al. Continental arc-island arc fluctuations, growth of crustal carbonates, and long-term climate change. Geosphere 9, 21-36 (2013).

6. Hirschmann, M. M. Comparative deep Earth volatile cycles: the case for $\mathrm{C}$ recycling from exosphere/mantle fractionation of major $\left(\mathrm{H}_{2} \mathrm{O}, \mathrm{C}, \mathrm{N}\right)$ volatiles and from $\mathrm{H}_{2} \mathrm{O} / \mathrm{Ce}$, $\mathrm{CO}_{2} / \mathrm{Ba}$, and $\mathrm{CO}_{2} / \mathrm{Nb}$ exosphere ratios. Earth and Planetary Science Letters 502, 262-273 (2018). 